Further Studies on the Softening of Rigid PVC by Aqueous Solutions of Organic Solvents

Louise V. Parker and Thomas A. Ranney October 1996
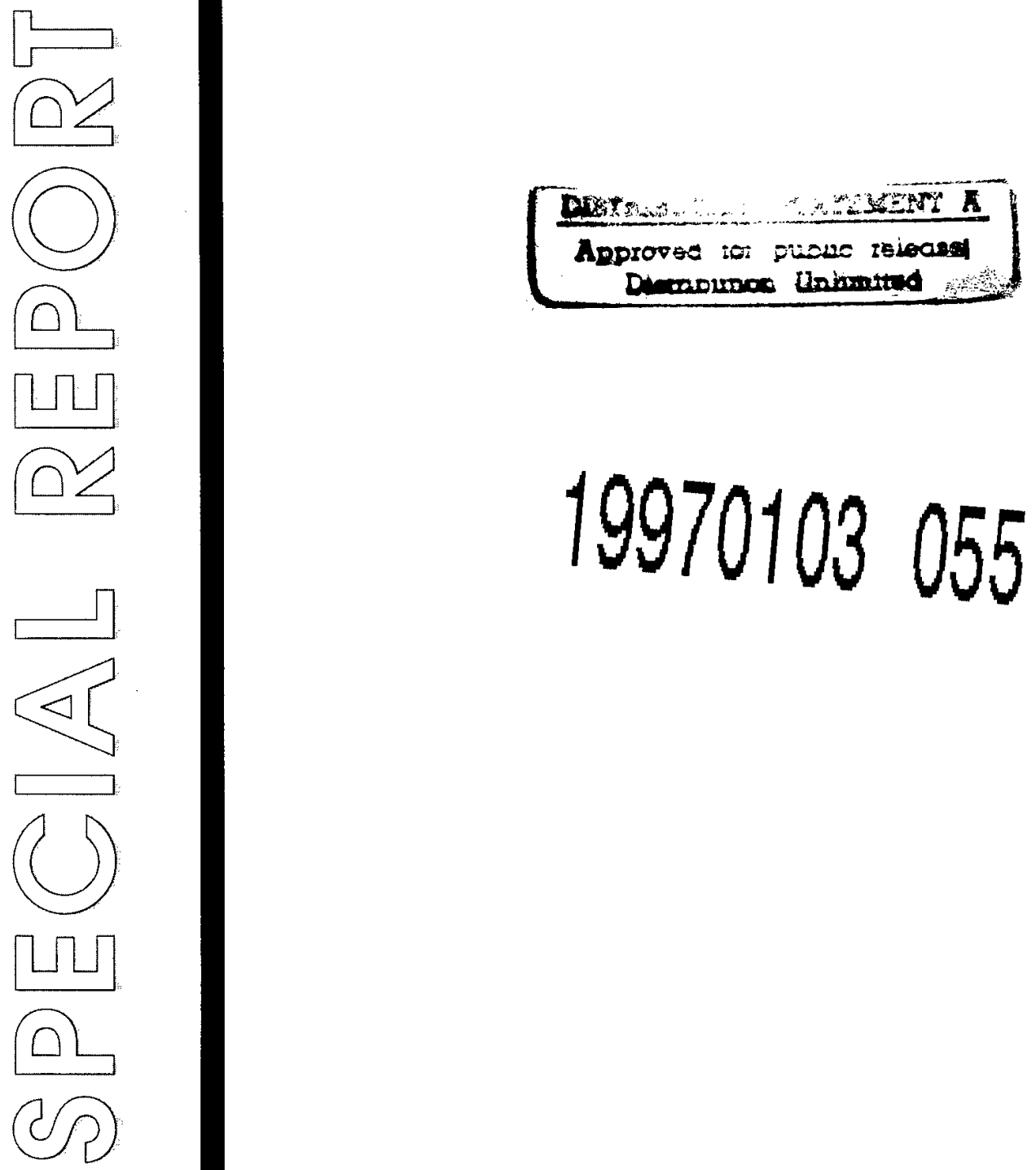
Abstract: In this study, small pieces of PVC well casing were exposed to relatively low activities (or relative solubilities) of TCE and methylene chloride for 12 months. PVC pieces were also exposed to aqueous solutions containing several organic chemicals that were either solvents or swelling agents of PVC. In addition, small pieces of PVC were exposed to aque- ous solutions containing organic chemicals that were either PVC solvents or swelling agents and were totally miscible in water. These studies revealed that there is an interactive effect among these chemicals when dissolved in water. However, softening does not appear to occur in any solutions where the sum of the relative solubilities is less than 0.1 .

\section{How to get copies of CRREL technical publications:}

Department of Defense personnel and contractors may order reports through the Defense Technical Information Center: DTIC-BR SUITE 0944

8725 JOHN J KINGMAN RD

FT BELVOIR VA 22060-6218

Telephone 18002253842

E-mail help@dtic.mil

msorders@dtic.mil

WWW http://Www.dtic.dla.mil/

All others may order reports through the National Technical Information Service:

NTIS

5285 PORT ROYAL RD

SPRINGFIELD VA 22161

Telephone 17034874650

17034874639 (TDD for the hearing-impaired)

E-mail orders@ntis.fedworld.gov

WWW http://Www.fedworld.gov/ntis/ntishome.html

A complete list of all CRREL technical publications is available from:

USACRREL (CECRL-TL)

72 LYME RD

HANOVER NH 03755-1290

Telephone 16036464338

E-mail techpubs@crrel.usace.army.mil

For information on all aspects of the Cold Regions Research and Engineering Laboratory, visit our World Wide Web site: http://www.crrel.usace.army.mil 


\section{Special Report 96-26}

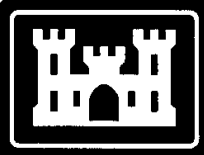

US Army Corps

of Engineers

Cold Regions Research \&

Engineering Laboratory

\section{Further Studies on the Softening of Rigid PVC by Aqueous Solutions of Organic Solvents}

Louise V. Parker and Thomas A. Ranney

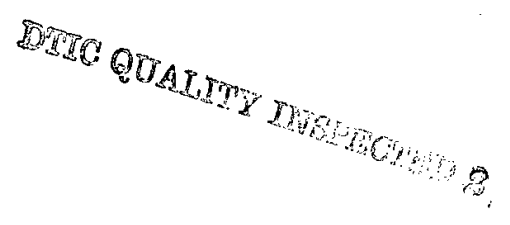




\section{PREFACE}

This report was prepared by Louise V. Parker, Research Physical Scientist, Applied Research Division, Research and Engineering Directorate, U.S. Army Cold Regions Research and Engineering Laboratory (CRREL), Hanover, New Hampshire, and Thomas A. Ranney, Staff Scientist, Science and Technology Corporation, Hanover, New Hampshire. Funding for this work was provided by the U.S. Army Environmental Center (USAEC), Aberdeen Proving Ground, Maryland, Martin H. Stutz, Project Monitor.

We thank Martin Stutz and AEC for their support of this work; Robert Forest, CRREL, for carefully cutting the PVC pieces; and Daniel Leggett and James Cragin, Research Chemists at CRREL, for their technical reviews of this manuscript.

This publication reflects the personal views of the authors and does not suggest or reflect the policy, practices, programs, or doctrine of the U.S. Army or Government of the United States. The contents of this report are not to be used for advertising or promotional purposes. Citation of brand names does not constitute an official endorsement or approval of the use of such commercial products. 


\section{CONTENTS}

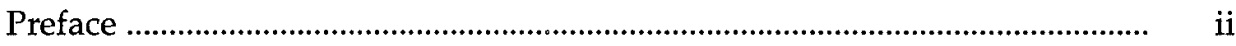

Introduction .................................................................................................

Methylene chloride studies ....................................................................... 2

Trichloroethylene studies .............................................................................

Studies on aqueous solutions that contain several organic solutes ............ 4

Aqueous solutions containing organics that are miscible in water ............. 4

Purpose of this study .....................................................................................

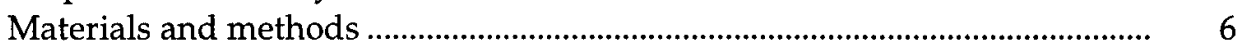

Long-term methylene chloride study ………………..................................

Long-term TCE study ................................................................................... 6

Studies on aqueous solutions that contain several organic solutes ............ $\quad 7$

Studies on aqueous solutions containing organics that are miscible

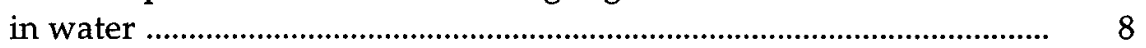

Results and discussion ......................................................................................

Long-term methylene chloride studies ......................................................... 8

Long-term TCE studies ................................................................................... 9

Studies on aqueous solutions that contain several organic solutes ............ $\quad 10$

Studies on aqueous solutions containing organics that are miscible in water

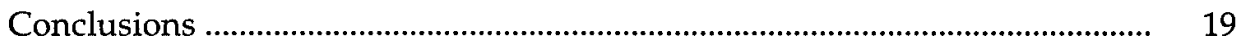

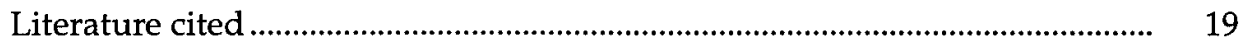

Appendix A: Percent weight gain in PVC exposed to various neat

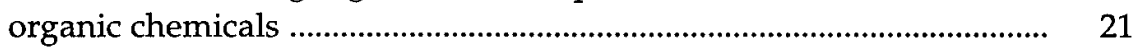

Abstract .......................................................................................................... 23

\section{ILLUSTRATIONS}

Figure

1. Flory-Huggins isotherms for various values of $\chi$ and approximate composition for softening of PVC at room temperature

\section{TABLES}

Table

1. Literature values for the Flory-Huggins interaction parameter, $\chi \ldots \ldots . . \quad 1$

2. Relative solubility and molarity of PVC solvent and swelling agents used in the test solutions 
3. Listing of 18 PVC solvent and swelling agents used in studies and their aqueous solubilities.

4. Hardness readings and percent weight gain of PVC exposed to methylene chloride solutions

5. Hardness readings and percent weight gain of PVC exposed to TCE solutions

6. Hardness readings and percent weight gain of PVC exposed to aqueous solutions of several organic solutes (short-term study) ....

7. Hardness readings and percent weight gain of PVC exposed to aqueous solutions of methylene chloride and TCE

8. Hardness readings and percent weight gain of PVC exposed to aqueous solutions of several organic solutes (first long-term study)

9. Hardness readings and percent weight gain of PVC exposed to aqueous solutions of several organic solutes (second longterm study)

10. Hardness readings and percent weight gain of PVC exposed to acetone solutions

11. Hardness readings and percent weight gain of PVC exposed to aqueous solutions of methylene chloride and acetone 


\title{
Further Studies on the Softening of Rigid PVC by Aqueous Solutions of Organic Solvents
}

\author{
LOUISE V. PARKER AND THOMAS A. RANNEY
}

\section{INTRODUCTION}

It has been known for some time that some neat (undiluted) organic solvents can dissolve or swell PVC well casings and screens. Products that can dissolve PVC are referred to as PVC solvents, and products that do not dissolve PVC but can cause it to swell are referred to as swelling agents of PVC. There has been concern that PVC casings and screens might be degraded by well water containing ppm and ppb levels of these chemicals. In the past few years, we have conducted a series of studies (Taylor and Parker 1990, Parker et al. 1992, Parker and Ranney 1994, 1995) to address this issue.

The solvent interaction parameter $(\chi)$ used in the Flory-Huggins equation* has been commonly used as a measure of the solvent or swelling power of a particular organic solvent (Berens 1985, Vonk 1985, 1986, Jenkins et al. 1986). Table 1 gives $\chi$ values for a number of organic chemicals that were derived experimentally ${ }^{\dagger}$ by Berens (1985) at $30^{\circ} \mathrm{C}$ and by Vonk (1985) at $20^{\circ} \mathrm{C}$. PVC is reported to be softened only by solvents with a $\chi$ value less than 1 (Berens 1985) or 1.2 (Vonk 1985); the lower the number the greater the solvent or swelling power. Also, a neat solvent with a $\chi$ value less

* The Flory-Huggins equation relates activity $(a)$ to the volume fraction $\left(V_{1}\right)$ of the organic chemical in the polymer as follows:

$$
\ln (a)=\ln V_{1}+\left(1-V_{1}\right)+\chi\left(1-V_{1}\right)^{2}
$$

where $\chi$ is the Flory-Huggins interaction parameter.

+ Berens (1985) and Vonk (1985) derived $\chi$ by exposing PVC to different activities of organic chemicals in vapor and solution.
Table 1. Literature values for the Flory-Huggins interaction parameter, $\chi$.

\begin{tabular}{|c|c|c|}
\hline Organic chemical & $\begin{array}{c}\text { From } \\
\text { Berens (1985) }\end{array}$ & $\begin{array}{c}\text { From } \\
\text { Vonk (1985) }\end{array}$ \\
\hline acetone & 0.61 & - \\
\hline aniline & - & 0.87 \\
\hline benzene & 0.83 & 0.83 \\
\hline 2-chloroaniline & - & 0.58 \\
\hline 3-chloroaniline & - & 0.61 \\
\hline chlorobenzene & - & 0.66 \\
\hline chloroform & 0.64 & 一 \\
\hline 1,2-chlorotoluene & - & 0.74 \\
\hline 1,3-chlorotoluene & - & 0.69 \\
\hline 1,4-chlorotoluene & 一 & 0.75 \\
\hline 1,2-dichlorobenzene & 一 & 0.63 \\
\hline 1,3-dichlorobenzene & - & 0.74 \\
\hline 1,1-dichloroethane & $<0.68$ & - \\
\hline 1,2-dichloroethane & $<0.55$ & 0.56 \\
\hline 1,2-dichloropropane & 0.68 & 0.65 \\
\hline di-isopropylketone & 一 & 0.56 \\
\hline ethylbenzene & 一 & 0.89 \\
\hline n-methylaniline & - & 0.59 \\
\hline methylene chloride & $<0.53$ & 0.55 \\
\hline methyl ethyl ketone & - & 0.54 \\
\hline nitrobenzene & 一 & 0.54 \\
\hline propylbenzene & - & 1.91 \\
\hline 1,1,2,2-tetrachloroethane & - & 0.59 \\
\hline tetrachloroethylene & 1.17 & 1.58 \\
\hline toluene & 0.80 & 0.82 \\
\hline 1,2,4-trichlorobenzene & - & 1.52 \\
\hline 1,1,1-trichloroethane & 0.85 & 0.92 \\
\hline 1,1,2-trichloroethane & $<0.56$ & 0.58 \\
\hline trichloroethylene & 0.88 & 0.90 \\
\hline $1,3,5$ trimethylbenzene & - & 2.52 \\
\hline vinyl chloride & 0.98 & - \\
\hline xylene & 0.88 & - \\
\hline 1,2-xylene & - & 0.76 \\
\hline 1,3-xylene & - & 0.87 \\
\hline 1,4-xylene & - & 0.86 \\
\hline
\end{tabular}




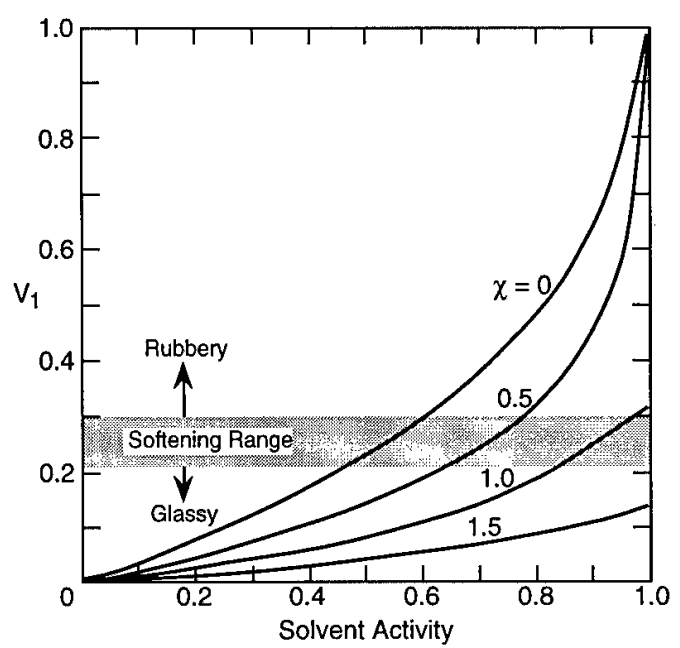

Figure 1. Flory-Huggins isotherms for various values of $\chi$ and approximate composition for softening of PVC at room temperature (from Berens 1985).

than 0.5 reportedly can completely dissolve PVC (Berens 1985). According to Vonk (1985), PVC is nearly inert to organic solvents if their $\chi$ value is greater than 3 (e.g., alcohols, aliphatic hydrocarbons, and organic acids).

According to Berens (1985), at ambient temperatures, rigid PVC can be softened only by PVC solvents or strong swelling agents at activities greater than 0.5 . The less aggressive the solvent (i.e., the higher the $\chi$ value), the higher the activity required to cause softening. Figure 1 shows the isotherms Berens derived using the FloryHuggins equation for various values of $\chi$ and the approximate softening range for PVC at $30^{\circ} \mathrm{C}$. Berens predicted that for lower temperatures (such as those commonly encountered in groundwater), slightly higher activities would be needed to cause softening.

The activity of an organic chemical in aqueous solution can be approximated by dividing the concentration of the compound in solution $(C w)$ by its solubility in water (Cws) (Berens 1985, Vonk 1986, Holsen 1988). However, the true relationship between activity $(a), C w$, and $C w s$ is:

$$
a=\gamma \frac{C w}{C w s}
$$

where $\gamma$ is the activity coefficient (Holsen 1988).

According to Holsen (1988), $\gamma$ is equal to unity when there are no interacting forces between the molecules; these forces become important at high but still unsaturated conditions. At lower concentrations, $\gamma$ has been considered equal to unity partially because of the lack of experimental data. Therefore, at high concentrations or when there are interacting forces between the molecules, estimates of activity using solubility may be inaccurate.

In this paper, we will use the term "relative solubility" to express $C w / C w s$ and thus estimate activity. However, we should point out that there also can be significant imprecision with this term. While it is known that aqueous solubilities vary with temperature, we have also found that for some organic compounds, the reported solubility can vary 1 or 2 orders of magnitude at the same temperature. Montgommery and Welkom (1990) have compiled aqueous solubility data from a number of sources. As an example of the variability we have observed, two of the values they report for the solubility of 1,1-dichloroethylene at $25^{\circ} \mathrm{C}$ are $273 \mathrm{mg} / \mathrm{L}$ and 5,000 $\mathrm{mg} / \mathrm{L}$.

Berens (1985) concluded that if aqueous solutions of solvents are going to cause softening of rigid PVC, the pure (or neat) solvent must be able to soften or dissolve PVC and must exist in solution at a concentration that exceeds one-half its solubility in water (activity $>0.5$ ). However, one criticism of Berens' work is that the various test (activities) solutions he used in his experiments were prepared by dissolving the organic solvents in polyethylene glycol and thus he never actually tested aqueous solutions of these organic solvents. Since one would expect that the partitioning of these organic solutes between the dissolved state and the polymer would differ between glycol and water, studies that use aqueous solutions of PVC solvents should be conducted to confirm Berens' predictions. While Vonk did use aqueous solutions of organics in his studies, we were unable to find a thorough discussion of his methods that was available in English. Therefore, our laboratory conducted a series of studies (Parker et al. 1992, Parker and Ranney 1994, 1995) to confirm Berens' predictions for PVC solvents and swelling agents in aqueous solutions. Following is a summary of our findings to date.

\section{Methylene chloride studies}

The first test solutions that were tested contained methylene chloride. Vonk (1985) reported that the $\chi$ value of methylene chloride is 0.55 , while Berens (1985) did not give a value for $\chi$ but reported that it is less than 0.53 . We (Ranney and Parker 1995) have observed pieces of PVC well casing dissolve when placed in neat methylene chloride. Thus, if Berens (1985) is correct in say- 
ing that any organic chemical with a $\chi$ value less than 0.5 can dissolve PVC, the true $\chi$ value for methylene chloride remains undefined but is less than 0.5 .

In a previous study (Parker and Ranney 1994), we found that after one week of exposure, PVC pieces exposed to aqueous solutions of methylene chloride with a relative solubility of 0.6 had hardness readings that were significantly lower than the control samples, and these samples were rubbery in that they could easily be bent by hand. (In all our studies, we use a Barcol Impressor to determine hardness.) Samples exposed to solutions with a relative solubility of 0.8 were also similarly affected, with significant changes in the hardness readings after only four hours. While these findings agree with Berens' (1985) predictions for PVC exposed to aqueous solutions with an activity of 0.8 , Berens would not predict that PVC exposed to solutions with an activity, or relative solubility, of 0.6 would become rubbery unless the true value of $\chi$ was very close to 0 . We were not able to find in Berens' paper how he determined softening.

In a subsequent study (Parker and Ranney 1994), we were able to determine that there were significant changes in the hardness readings of test pieces that were exposed to aqueous solutions of methylene chloride with relative solubilities of $0.4,0.2$, and 0.1 for 20 weeks. However, none of these samples were actually rubbery or pliable. We concluded that it appeared that softening had begun to occur at much lower relative solubilities, or activities ( 0.1 to 0.4 ), than had been previously reported or predicted by Berens (1985). Because we conducted our own solubility tests to confirm the aqueous solubility of methylene chloride, we do not feel that our test results can be explained away by assuming the solubility value we used is incorrect.

According to Berens (1985), diffusion of organic permeants is slowest (Fickian) at activities less than 0.25. However, Vonk $(1985,1986)$ felt that diffusion would be Fickian for the poorer PVC swelling agents (e.g., alkylated aromatics) at activities less than 0.25 , but for the solvents and the better swelling agents (i.e., anilines, chlorinated hydrocarbons, ketones, and nitrobenzenes) the activity should be less than 0.1 . If this is the case, we would not expect to observe any changes in the hardness readings of samples exposed to solutions of methylene chloride (a solvent) with relative solubilities less than 0.1 . The results from this study tend to support this hypothesis since the hardness readings of the samples that were exposed to solutions with a relative solubility of 0.05 were not significantly different from the controls.

We proposed that only partial softening occurs at the lower relative solubilities $(0.1$ to 0.4$)$ and that these samples will never actually become rubbery or pliable. Examination of Berens' isotherms (Fig. 1) indicates that some samples do become partially softened but never actually become rubbery. We concluded that a longer-term study was necessary to resolve whether softening progresses further with time, and the lowest relative solubility at which softening occurs.

\section{Trichloroethylene studies}

We conducted another series of studies using trichloroethylene (TCE). TCE is a common environmental pollutant and is a relatively good swelling agent of PVC. There is close agreement between the $\chi$ value of Berens (1985), 0.88, and that of Vonk (1985), 0.90. When we (App. A, Ranney and Parker 1995) subjected small pieces of PVC well casing to neat (undiluted) TCE, we found that the test pieces showed signs of swelling and softening after only one day. However, TCE did not dissolve the PVC pieces. Thus, our experimental work appears to confirm that TCE is a good swelling agent of PVC but that it is not a solvent.

We conducted two studies where pieces of PVC were exposed to aqueous solutions of TCE with a range of relative solubilities (0.2 to 1.0) (Parker and Ranney 1994). Samples that were exposed to solutions with relative solubilities of 0.8 and 1.0 had Barcol readings that were significantly lower than the controls. The samples that were exposed to the solutions with a relative solubility of 0.8 never became pliable or rubbery, while those exposed to the 1.0 relative solubility solutions were pliable by the end of the study (77 days). Generally, the results for TCE agree with what would be predicted using Berens' isotherms (Fig. 1): PVC would be softened by TCE when the activity, or relative solubility, is 0.8 or greater and would become rubbery if the relative solubility was 0.95 (at $30^{\circ} \mathrm{C}$ ).

Samples that were exposed to solutions with a relative solubility of 0.6 had hardness readings that were significantly different from the controls in the first study (68 days) but not in the second study (77 days). We were not certain why the results for the two studies differed. We thought that if the unsoftened samples had been given 
more time that softening might have occurred, or it might have been due to the heterogeneous nature of PVC. We noted that at the lower relative solubilities, the test pieces continued to gain weight, and therefore equilibrium was not reached. We concluded that a longer-term study should resolve the lowest relative solubility that can soften PVC.

\section{Studies on aqueous solutions that contain several organic solutes}

One question that has not been addressed in the literature is what effect does an aqueous solution that contains several different PVC solvents or swelling agents have on PVC. This is an important question for the groundwater monitoring industry since most contaminated groundwater contains several organic contaminants, each at $\mathrm{ppb}$ or ppm levels. In cases where there is only one organic solute in a solution, there can be interactions between the organic and the polymer, the organic and water, and among the organic molecules. In cases where there is more than one organic solute, there can be all those interactions as well as interactions among the various organic solutes (i.e., $a$ and $b, b$ and $c$, $a$ and $c$, etc.). We have conducted several studies that have looked at softening by solutions containing multiple organic solutes.

In the first study, we (Parker and Ranney 1994) found that after two days' contact, the hardness readings of samples exposed to an aqueous solution that contained three PVC solvents or swelling agents were significantly lower than those of the controls, and these samples were rubbery. The test solution contained methylene chloride, 1,1,2trichloroethane, and 1,2-dichloroethane, each with a relative solubility of 0.3 . The $\chi$ values for these three compounds are reported to be less than 0.6 (Table 1). At this relative solubility, Berens would predict that none of these organic solutes should be able to soften PVC by themselves. Our own studies (Parker and Ranney 1994) have shown that methylene chloride was able to cause softening at a similar relative solubility $(0.4)$, but it took eight weeks. The test solution in this study behaved more like a test solution containing methylene chloride at a relative solubility of 0.8 , which softened the PVC pieces almost immediately (Parker and Ranney 1994).

In a follow-up study (Parker and Ranney 1995), an aqueous solution that contained 18 PVC solvents and swelling agents, each with a relative solubility of 0.05 , softened PVC. There was a sig- nificant change in the Barcol readings after only one day, and after 14 days several of the test pieces were noticeably softened when tested manually, although none actually became pliable. It is clear from these studies that there is a cumulative or possibly synergistic effect when several PVC solvents and/or swelling agents are present in an aqueous solution.

We thought that the sum of the relative solubilities (or activities) of the organic solutes in the test solution might prove to be useful in estimating the ability of a solution to soften PVC. In this study (Parker and Ranney 1995), the sum of the relative solubilities of the organic solutes was 0.9 . This solution was more aggressive than a solution containing a PVC swelling agent (the TCE solution) with a relative solubility of 1.0 , but less aggressive than a solution containing a PVC solvent (the methylene chloride solution) with a relative solubility of 0.8 (Parker and Ranney 1994). Although it does not explain how the organic solutes interact with the polymer, water, or each other, the sum of the relative solubilities does give some measure of the ability of an aqueous solution containing two or more organic solutes to degrade PVC.

We concluded that there were a number of unanswered questions, such as 1) whether a mixture of organic solutes that are at even lower relative solubilities could soften PVC, 2) whether PVC solvents and swelling agents have any synergistic effect on other, poorer swelling agents, and 3) what happens in solutions that contain a number of solutes with varying but very low relative solubilities?

\section{Aqueous solutions containing organics that are miscible in water}

Another issue that had not been addressed in the literature prior to our studies was whether aqueous solutions of PVC solvents and swelling agents, which are also completely miscible in water, can soften PVC. It is impossible to calculate the relative solubility of these solutions, because this involves dividing the analyte's concentration by an infinitely large number. We have conducted several studies that look at this issue.

In our most recent paper (Parker and Ranney 1995), PVC test pieces were exposed to varying concentrations of aqueous solutions containing one of four organic chemicals that were totally miscible in water: acetone, tetrahydrofuran, dimethylformamide, and pyridine. Acetone is a good swelling agent of PVC $(\chi=0.61$ [Berens 
1985]). There are no $\chi$ values available for the other three chemicals, but tests by our laboratory indicate that they are all PVC solvents (App. A, Ranney and Parker 1995). In fact, tetrahydrofuran is commonly used as a component of PVC glues.

We (Parker and Ranney 1995) found that the test solutions containing tetrahydrofuran were the most aggressive. After seven days, a $60 \%$ solution $(8.4 \mathrm{M})$ dissolved the PVC pieces. By the end of a 20-week study that used lower concentrations, the hardness readings of the samples exposed to the lowest concentration tested $(0.01 \%$ or 0.0014 M) were significantly lower than the controls. However, none of these samples were noticeably softened when tested manually, even the samples exposed to the highest concentration tested $(10 \%$ or $1.4 \mathrm{M}$ ). Although there is a lot of variability in the weight change data, by the end of the study there was no additional weight gain in the samples that were exposed to the $1.0,0.1$, and $0.01 \%$ solutions. This may indicate that these solutions have reached equilibrium. If this is the case, then we would not expect any additional softening to occur.

The acetone solution was the next most aggressive solution (Parker and Ranney 1995). After seven days, the hardness readings for samples exposed to the $60 \%(10.2 \mathrm{M})$ solutions were significantly lower than the controls, and the samples were pliable when tested manually (i.e., could be bent in half easily). In a longer-term study (20 weeks) (Parker and Ranney 1995), there was no significant change in the hardness readings of samples that were exposed to the $2.5 \%(0.43 \mathrm{M})$ and $5 \%(0.86 \mathrm{M})$ solutions. There was a significant change in the Barcol readings of samples exposed to the $10 \%(1.7 \mathrm{M}), 20 \%$ ( $3.4 \mathrm{M}$ ), and $40 \%$ $(6.9 \mathrm{M})$ solutions. However, none of these samples were noticeably softened when tested manually. Although the weight gain data were highly variable, it did appear that the samples exposed to the $40 \%, 10 \%$, and the $5 \%$ solutions had reached equilibrium. If this is the case, we would not expect further softening to occur. However, this is unproven at this time.

Our initial study (Parker and Ranney 1995) showed that aqueous solutions of pyridine were not highly aggressive. Even the $60 \%$ solution had no effect on the hardness readings after seven days. However, after a 20-week study (Parker and Ranney 1995), there was a significant change in the hardness readings for the samples exposed to the lowest concentration tested ( $20 \%$ or $2.5 \mathrm{M})$. Samples exposed to the highest concentration tested $(80 \%$ or $10 \mathrm{M})$ were actually pliable, i.e., easily bent in half.

The dimethylformamide solution was the least aggressive solution. During a 20-week study (Parker and Ranney 1995), only the test pieces exposed to the $60(8.2 \mathrm{M})$ and 80 percent $(10.9 \mathrm{M})$ solutions had hardness readings that were significantly lower than the controls. The samples that were exposed to the $80 \%$ solution were also pliable. Because there was no additional weight gain in any of these samples during the last four weeks of the study, equilibrium may have been reached.

It is clear from this study that PVC solvents and swelling agents that are completely miscible in water can soften PVC when mixed with water. These results are puzzling in that the aqueous solutions of acetone were more aggressive than the aqueous solutions of the dimethylformamide and pyridine, and yet our laboratory studies show that these two chemicals are more aggressive than acetone (App. A, Ranney and Parker 1995). Therefore, we would expect that the aqueous acetone solutions would be the least aggressive solutions. It appears that the ability of aqueous solutions of these chemicals does not completely correlate with the neat chemicals' ability to dissolve or swell PVC. This can be related to other interactions that occur in aqueous solution. According to Leggett (pers. comm. 1995*) acetone is less basic than the other solutes and would interact less strongly with water, and thus an aqueous solution would have a higher activity on a molar basis.

\section{PURPOSE OF THIS STUDY}

The purpose of this study was to determine:

1) whether softening progresses further in those solutions already showing a significant change in hardness readings but are not yet pliable?

2) for solutions with single organic solutes, what is the lowest relative solubility where softening occurs?

3) for solutions with multiple organic solutes, what is the lowest relative solubility where softening occurs?

4) for solutions with multiple organic solutes, how well does the sum of the relative solubilities of the solutes in the solution correlate with the solution's ability to soften PVC?

* D. Leggett, Research Chemist, USA Cold Regions Research and Engineering Laboratory, Hanover, New Hampshire. 
5) what occurs in an aqueous solution that contains a number of PVC solvents and swelling agents at varying relative solubilities?

6) in solutions that contain several organic solutes, do solutes that are solvents and swelling agents of PVC have some type of synergistic effect on poorer swelling agents?

7) what is the lowest concentration of acetone in aqueous solution that can soften PVC?

8) what occurs when PVC solvents and swelling agents that are miscible in water are also present in an aqueous solution with other PVC solvents and swelling agents?

\section{MATERIALS AND METHODS}

Small pieces of PVC were cut from 2-in.- (5.1 $\mathrm{cm}$ ) diameter, schedule 40 well casing. The overall dimensions of the pieces were approximately $9 \times 9 \times 1.1 \mathrm{~mm}(\mathrm{~L} \times \mathrm{W} \times \mathrm{H})$, giving a total surface area of approximately $2.1 \mathrm{~cm}^{2}$ and approximate weight of $0.12 \mathrm{~g}$. Special care was taken to eliminate contamination from grease or oil during the cutting procedure. The pieces of PVC were washed by placing them in a glass beaker containing a $2 \%$ solution of Liquinox detergent and deionized (Millipore) water for 30 minutes, and stirring them intermittently with a glass rod for approximately five minutes. The pieces were then rinsed with copious amounts of deionized water to ensure complete removal of the detergent, and were then spread on paper towels, blotted, and left to air dry.

All the test solutions were made up by adding appropriate volumes of the neat analyte (based on the density of the compound) to deionized water in volumetric flasks. To prevent any losses due to biological activity, mercuric chloride was added to the test solution so that the final concentration was $40 \mathrm{mg} / \mathrm{L}$. A glass-covered magnetic stirring bar was added to each flask, and the flasks were then filled with deionized water to within $\sim 1 \mathrm{~mL}$ of the top. This left a minimal head space once the glass stopper was inserted. The stoppers were then wrapped tightly with parafilm to reduce vapor loss and the solutions were mixed for a minimum of three days on magnetic stirring plates.

After mixing for several days, the solutions were checked with a magnifying glass to ensure that there were no undissolved droplets of solvent visible. Once it was determined that the organic(s) had dissolved, pre-weighed PVC pieces were added to $22-\mathrm{mL}$ borosilicate glass vials. The vials were then filled to capacity with the test solution so there was no headspace, and capped with Teflon-lined plastic caps. PVC pieces added to deionized water served as controls. In all the studies, there were five replicates for each type of solution (relative solubility) and time. The test samples were stored in the dark at room temperature. The ratio of surface area of PVC to solution volume was $0.079 \mathrm{~cm}^{2} / \mathrm{mL}$, and the ratio of solution volume to volume of PVC was approximately 310:1.

On the sampling day, the pieces of PVC were removed from the solution, placed on paper towels, blotted, and allowed to air dry for one minute before weighing $( \pm 0.0001 \mathrm{~g})$. In all cases, the pieces of PVC were handled using stainless steel forceps. Immediately after weighing, a Model 935 Barcol Impressor was used to measure the hardness of the PVC. A description on the use of the Barcol Impressor on rigid plastics can be found in ASTM Standard Test Method D 2583-87 (ASTM 1988). However, the impressor employed in this study is made for indenting softer plastics and is not the model described in the ASTM test method. This model was selected so that measurements could be taken during the softening process. The flexibility was also tested by holding the pieces with forceps and noting the amount of force necessary to bend the sample.

In all these studies, Analysis of Variance and Fisher's Protected Least Significant Difference (LSD) tests were performed on the Barcol readings and weights of the samples.

\section{Long-term methylene \\ chloride study}

In this study, the PVC test pieces were exposed to aqueous solutions of methylene chloride with the following relative solubilities: $0.01,0.05,0.1$, 0.2 , and 0.4 . Contact times were $3,6,9,12,15$, and 18 months. The test solutions were changed every six months. Relative solubilities were based upon a solubility of $19,000 \mathrm{mg} / \mathrm{L}$. Because Montgommery and Welkom (1990) listed a range of solubility values, we conducted our own solubility tests and then selected the published value that most closely agreed with our findings (Parker and Ranney 1994).

\section{Long-term TCE study}

In this study, PVC was exposed to aqueous solutions of TCE at five relative solubilities: 0.05 , $0.10,0.20,0.40$, and 0.60 . Contact times were the 
Table 2. Relative solubility and molarity of PVC solvent and swelling agents used in the test solutions.

\begin{tabular}{|c|c|c|c|c|c|c|}
\hline \multirow[b]{2}{*}{ Solvent } & \multirow{2}{*}{$\begin{array}{l}\text { Solubility } \\
(m g / L)\end{array}$} & \multirow{2}{*}{$\begin{array}{l}\text { Mol.wt. } \\
\text { (g/mole) }\end{array}$} & \multicolumn{2}{|c|}{ Solution A } & \multicolumn{2}{|c|}{ Solution B } \\
\hline & & & Rel. solubility & Molarity & Rel. solubility & Molarity \\
\hline bromodichloromethane & $4,500^{1}$ & $163.8^{1}$ & 0.08 & 0.022 & 0.07 & 0.019 \\
\hline chlorobenzene & $500^{1}$ & $112.56^{1}$ & 0.04 & 0.002 & 0.10 & 0.004 \\
\hline chloroform & $8,000^{1}$ & $119.38^{1}$ & 0.12 & 0.080 & 0.09 & 0.060 \\
\hline cyclohexanone & $23,000^{2}$ & $98.2^{2}$ & 0.09 & 0.211 & 0.12 & 0.281 \\
\hline 1,2-dichloroethane & $8,690^{1}$ & $98.96^{1}$ & 0.15 & 0.132 & 0.08 & 0.070 \\
\hline 1,1,2-trichloroethane & $4,500^{1}$ & $133.41^{1}$ & 0.10 & 0.034 & 0.04 & 0.013 \\
\hline methylene chloride & $19,000^{1}$ & $84.93^{1}$ & 0.05 & 0.112 & 0.02 & 0.045 \\
\hline methyl isobutyl ketone & $17,000^{1}$ & $100.2^{1}$ & 0.07 & 0.119 & 0.08 & 0.136 \\
\hline nitrobenzene & $1,900^{1}$ & $123.1^{1}$ & 0.08 & 0.012 & 0.15 & 0.023 \\
\hline$m$-nitrotoluene & $500^{1}$ & $137.13^{1}$ & 0.02 & 0.001 & 0.05 & 0.002 \\
\hline Total & & & & 0.725 & & 0.653 \\
\hline
\end{tabular}

same as the previous study, and the test solutions were changed every six months. An aqueous solubility of $1000 \mathrm{mg} / \mathrm{L}$ (Dean 1985) was used.

\section{Studies on aqueous solutions that contain several organic solutes}

\section{Short-term study}

In this study, we exposed PVC to two solutions containing ten PVC solvents and swelling agents (Table 2). Table 2 lists the aqueous solubility values we used to determine relative solubility. The sum of the relative solubilities of the organic solutes in the solutions was 0.80 , the relative solubility of each analyte varied from 0.02 to 0.15 , and the relative solubility of each analyte varied from solution A to solution B. Contact times were $8,24,72$, and 168 hours (seven days).

\section{Mid-term study}

The test pieces of PVC were exposed to a solution of either TCE, methylene chloride, or a combination of TCE and methylene chloride. The relative solubilities for methylene chloride were either 0 or 0.4 . The relative solubilities for the TCE were either $0,0.2,0.4$, or 0.6 . Contact times were 2,7 , 14,28 , and 56 days.

\section{First long-term study}

PVC test pieces were exposed to two aqueous solutions of 18 organic chemicals (Table 3 ) that we have found to be either solvents or swelling agents of PVC (App. A, Ranney and Parker 1995).
The solubilities of these 18 chemicals are also given in Table 3 . The protocol for this experiment differed from our other experiments in that smaller test pieces $(\sim 9 \times 9 \times 0.9 \mathrm{~mm})$ that were left over from our previous studies (Parker and Ranney 1994, 1995) were used. These dimensions made the total surface area $1.9 \mathrm{~cm}^{2}$,

Table 3. Listing of 18 PVC solvent and swelling agents used in studies and their aqueous solubilities.

\begin{tabular}{lr} 
& $\begin{array}{r}\text { Solubility } \\
(m g / L)\end{array}$ \\
\hline benzonitrile & $2,000^{3}$ \\
bromochloromethane & $16,691^{2}$ \\
bromodichloromethane & $4,500^{1}$ \\
bromoform & $3,010^{1}$ \\
chlorobenzene & $500^{1}$ \\
chloroform & $8,000^{1}$ \\
cyclohexanone & $23,000^{2}$ \\
dibromochloromethane & $4,000^{1}$ \\
1,2-dibromoethane & $4,300^{3}$ \\
1,2-dichloroethane & $8,690^{1}$ \\
cis-1,2-dichloroethylene & $7,700^{3}$ \\
trans-1,2-dichloroethylene & $6,300^{3}$ \\
methylene chloride & $19,000^{1}$ \\
methyl isobutyl ketone & $17,000^{1}$ \\
nitrobenzene & $1,900^{1}$ \\
m-nitrotoluene & $500^{1}$ \\
o-nitrotoluene & $600^{2}$ \\
1,1,2-trichloroethane & $4,500^{1}$ \\
\hline 1 Value taken from Montgommery and & \\
Welkom (1990). & \\
2 Value taken from Montgommery $(1991)$. \\
3 Value taken from Dean (1985).
\end{tabular}


the approximate weight $0.09 \mathrm{~g}$, the ratio of surface area to solution volume 0.076 , and the solution volume to PVC volume approximately 386:1. Another difference with this experiment was that the Teflon-lined caps were lined with aluminum foil to prevent any losses due to sorption by caps, and as a result mercuric chloride was not added to the test solutions because it would degrade the aluminum foil. The relative solubility of each of the analytes was either 0.010 or 0.020 . The sum of the relative solubilities of the organic solutes was either 0.18 or 0.36 , respectively. Samples were taken after 20 and 40 weeks' contact.

\section{Second long-term study}

In this study, pieces of PVC were exposed to four aqueous solutions of the same eighteen PVC solvents and swelling agents (Table 3 ). This time the relative solubility of the analytes was either $0.001,0.005$, 0.010 , or 0.020 . This makes the sum of the relative solubilities of the organic solutes either $0.018,0.09,0.18$, or 0.36, respectively. Samples were taken after $3,6,9,12,15$, and 18 months, and the test solutions were changed every six months.

\section{Studies on aqueous solutions containing organics that are miscible in water}

\section{Long-term acetone study}

In this study, pieces of PVC were exposed to aqueous solutions that contained the following percent acetone: $0.5 \%, 1 \%, 5 \%, 10 \%$, and $20 \%$ $(\mathrm{w} / \mathrm{v})$. Contact times were again 3 , $6,9,12,15$, and 18 months. The test solutions were changed every six months.

\section{Short-term study with acetone} and methylene chloride

PVC was exposed to different solutions containing methylene chloride and acetone. The relative solubility of the methylene chloride was 0.4 , while the concentration of acetone in the solution was either $0 \%$, $0.5 \%, 1.0 \%, 5.0 \%, 10 \%$, or $20 \%$ (w/ v). Contact times were $2,4,7,14$, and 21 days.

\section{RESULTS AND DISCUSSION}

\section{Long-term methylene} chloride studies

Table 4 gives the hardness readings and percent weight gain data for samples exposed to aqueous solutions with relative solubilities of $0.01,0.05$, $0.10,0.20$, and 0.40 . After 18 months' exposure, there was no significant change in the hardness readings of samples that were exposed to aqueous solutions of methylene chloride with relative solubilities that were less than 0.1 . With one ex-

Table 4a. Hardness (Barcol) readings of PVC exposed to methylene chloride solutions.

\begin{tabular}{cllllll}
$\begin{array}{c}\text { Relative } \\
\text { solubility }\end{array}$ & \multicolumn{5}{c}{ Contact time, months } \\
\cline { 2 - 7 } & 3 & 6 & 9 & 12 & 15 & 18 \\
\hline 0.00 & 71 & 74 & 78 & 77 & 78 & 78 \\
0.00 & 71 & 73 & 79 & 77 & 78 & 80 \\
0.00 & 72 & 73 & 78 & 78 & 76 & 79 \\
0.00 & 73 & 74 & 76 & 76 & 78 & 80 \\
0.00 & 73 & 74 & 80 & 78 & 78 & 78 \\
$\bar{X}$ & 72.0 & 73.6 & 78.2 & 77.2 & 77.6 & 79.0 \\
0.01 & 73 & 74 & 78 & 77 & 78 & 79 \\
0.01 & 72 & 74 & 79 & 79 & 77 & 79 \\
0.01 & 71 & 72 & 80 & 76 & 78 & 80 \\
0.01 & 70 & 73 & 77 & 78 & 79 & 79 \\
0.01 & 74 & 73 & 78 & 77 & 77 & 78 \\
$\bar{X}$ & 72.0 & 73.2 & 78.4 & 77.4 & 77.8 & 79.0 \\
0.05 & 72 & 74 & 76 & 77 & 76 & 77 \\
0.05 & 72 & 74 & 78 & 78 & 79 & 80 \\
0.05 & 71 & 73 & 79 & 76 & 78 & 79 \\
0.05 & 70 & 73 & 76 & 76 & 76 & 78 \\
0.05 & 70 & 72 & 77 & 78 & 77 & 78 \\
$\bar{X}$ & 71.0 & 73.2 & 77.2 & 77.0 & 77.2 & 78.4 \\
0.10 & 71 & 74 & 76 & 76 & 76 & 77 \\
0.10 & 72 & 74 & 79 & 74 & 78 & 76 \\
0.10 & 71 & 74 & 77 & 77 & 75 & 78 \\
0.10 & 72 & 73 & 78 & 76 & 76 & 77 \\
0.10 & 71 & 73 & 80 & 75 & 74 & 75 \\
$\bar{X}$ & 71.4 & 73.6 & 78.0 & $75.6^{*}$ & $75.8 *$ & $76.6^{*}$ \\
0.20 & 71 & 73 & 77 & 75 & 73 & 77 \\
0.20 & 71 & 74 & 76 & 76 & 74 & 76 \\
0.20 & 70 & 72 & 77 & 75 & 73 & 74 \\
0.20 & 71 & 73 & 76 & 73 & 74 & 74 \\
0.20 & 72 & 73 & 74 & 77 & 73 & 73 \\
$\bar{X}$ & 71.0 & 73.0 & $76.0^{*}$ & $75.2^{*}$ & $73.4^{*}$ & $74.8^{*}$ \\
0.40 & 69 & 72 & 74 & 74 & 73 & 71 \\
0.40 & 70 & 72 & 77 & 74 & 72 & 72 \\
0.40 & 71 & 71 & 76 & 75 & 71 & 74 \\
0.40 & 70 & 72 & 76 & 75 & 71 & 74 \\
0.40 & 69 & 73 & 76 & 73 & 72 & 73 \\
$\bar{X}$ & $69.8^{*}$ & $72.0^{*}$ & $75.8^{*}$ & $74.2^{*}$ & $71.8^{*}$ & $72.8^{*}$ \\
\hline & & & & & & \\
\hline
\end{tabular}

*Significantly different from controls. 
ception, there was also no significant change in the weight change data. These results support our hypothesis that softening will not be detected at activities where diffusion is reported to be slowest (Fickian), i.e., for PVC solvents and better swelling agents less than 0.1 (Vonk 1985, 1986).

Table 4b. Percent weight gain of PVC exposed to methylene chloride solutions.

\begin{tabular}{|c|c|c|c|c|c|c|}
\hline \multirow{2}{*}{$\begin{array}{c}\text { Relative } \\
\text { solubility }\end{array}$} & \multicolumn{6}{|c|}{ Contact time, months } \\
\hline & 3 & 6 & 9 & 12 & 15 & 18 \\
\hline 0.00 & 0.13 & 0.24 & 0.26 & 0.20 & 0.33 & 0.17 \\
\hline 0.00 & 0.26 & 0.28 & 0.17 & 0.09 & 0.00 & 0.32 \\
\hline 0.00 & 0.15 & 0.35 & 0.35 & 0.28 & 0.25 & 0.19 \\
\hline 0.00 & 0.17 & 0.35 & 0.26 & 0.16 & 0.27 & 0.16 \\
\hline 0.00 & 0.25 & 0.35 & 0.27 & 0.14 & 0.20 & 0.26 \\
\hline $\bar{X}$ & $0.19^{a}$ & $0.31^{a, b}$ & $0.26^{\mathrm{a}}$ & $0.17^{a}$ & $0.21^{\mathrm{a}}$ & $0.22^{\mathrm{a}}$ \\
\hline S.D. & 0.06 & 0.05 & 0.07 & 0.07 & 0.13 & 0.07 \\
\hline 0.01 & 0.35 & 0.18 & 0.26 & 0.26 & 0.35 & 0.17 \\
\hline 0.01 & 0.17 & 0.26 & 0.35 & 0.34 & 0.17 & 0.24 \\
\hline 0.01 & 0.25 & 0.27 & 0.41 & 0.36 & 0.16 & 0.21 \\
\hline 0.01 & 0.34 & 0.36 & 0.35 & 0.27 & 0.08 & 0.18 \\
\hline 0.01 & 0.41 & 0.42 & 0.42 & 0.35 & 0.34 & 0.08 \\
\hline $\bar{X}$ & $0.30^{\mathrm{a}}$ & $0.30^{\mathrm{a}}$ & $0.36^{a}$ & $0.32^{\mathrm{a}, \mathrm{b}}$ & $0.22^{\mathrm{a}}$ & $0.18^{a}$ \\
\hline S.D. & 0.09 & 0.09 & 0.06 & 0.05 & 0.12 & 0.06 \\
\hline 0.05 & 0.44 & 0.25 & 0.40 & 0.34 & 0.27 & 0.35 \\
\hline 0.05 & 0.34 & 0.33 & 0.40 & 0.34 & 0.33 & 0.50 \\
\hline 0.05 & 0.34 & 0.44 & 0.36 & 0.31 & 0.24 & 0.17 \\
\hline 0.05 & 0.34 & 0.44 & 0.33 & 0.61 & 0.33 & 0.41 \\
\hline 0.05 & 0.24 & 0.25 & 0.34 & 0.34 & 0.25 & 0.28 \\
\hline $\bar{X}$ & $0.34^{\mathrm{a}}$ & $0.34^{a, b}$ & $0.37^{a}$ & $0.39 \mathrm{~b}, \mathrm{c}$ & $0.28^{\mathrm{a}}$ & $0.34^{\mathrm{a}, \mathrm{b}}$ \\
\hline S.D. & 0.07 & 0.09 & 0.03 & 0.12 & 0.04 & 0.13 \\
\hline 0.10 & 0.33 & 0.41 & 0.62 & 0.53 & 0.72 & 0.43 \\
\hline 0.10 & 0.37 & 0.41 & 0.55 & 0.42 & 0.52 & 0.64 \\
\hline 0.10 & 0.43 & 0.62 & 0.53 & 0.50 & 0.59 & 0.52 \\
\hline 0.10 & 0.26 & 0.69 & 0.64 & 0.54 & 0.60 & 0.58 \\
\hline 0.10 & 0.32 & 0.37 & 0.69 & 0.69 & 0.51 & 0.44 \\
\hline $\bar{X}$ & $0.34^{\mathrm{a}}$ & $0.50^{\mathrm{b}}$ & $0.60^{\mathrm{b}}$ & $0.54^{\mathrm{c}, \mathrm{d}}$ & $0.59^{b}$ & $0.52^{b, c}$ \\
\hline S.D. & 0.06 & 0.14 & 0.06 & 0.10 & 0.08 & 0.09 \\
\hline 0.20 & 0.75 & 1.01 & 0.74 & 0.74 & 0.82 & 0.60 \\
\hline 0.20 & 0.72 & 0.64 & 1.11 & 0.59 & 0.87 & 0.67 \\
\hline 0.20 & 0.87 & 0.76 & 0.66 & 0.61 & 0.92 & 0.58 \\
\hline 0.20 & 0.61 & 0.60 & 1.00 & 0.81 & 1.05 & 0.61 \\
\hline 0.20 & 0.65 & 0.75 & 0.83 & 0.85 & 0.84 & 0.59 \\
\hline $\bar{X}$ & $0.72^{b}$ & $0.75^{c}$ & $0.87^{c}$ & $0.72^{\mathrm{d}}$ & $0.90^{c}$ & $0.61^{\mathrm{c}}$ \\
\hline S.D. & 0.10 & 0.16 & 0.19 & 0.12 & 0.09 & 0.03 \\
\hline 0.40 & 1.33 & 1.39 & 1.69 & 2.38 & 2.37 & 2.18 \\
\hline 0.40 & 1.51 & 0.79 & 1.91 & 2.15 & 2.13 & 2.01 \\
\hline 0.40 & 1.65 & 1.01 & 1.66 & 1.94 & 1.67 & 2.20 \\
\hline 0.40 & 1.99 & 1.25 & 1.36 & 2.26 & 2.50 & 1.41 \\
\hline 0.40 & 1.43 & 1.39 & 1.66 & 1.67 & 2.01 & 1.97 \\
\hline $\bar{X}$ & $1.58^{c}$ & $1.17^{\mathrm{d}}$ & $1.66^{d}$ & $2.08^{e}$ & $2.14^{\mathrm{d}}$ & $1.95^{\mathrm{d}}$ \\
\hline S.D. & 0.26 & 0.26 & 0.19 & 0.28 & 0.32 & 0.32 \\
\hline
\end{tabular}

S.D. = standard deviation

Values with different letters, taken at the same time, are significantly different.
Hardness readings of samples that were exposed to aqueous solutions with a relative solubility of 0.1 were significantly lower than the controls after one year. Samples exposed to solutions with higher relative solubilities $(0.2,0.4)$ softened earlier in the study. However, none of these samples were pliable. Presumably these materials become slightly softened but never become pliable or rubbery. This conclusion is supported by the fact that there does not appear to be much additional weight gain after the first three to six months for any of the samples exposed to the solutions with relative solubilities of 0.10 and 0.20 and after 12 months in samples exposed to solutions with a relative solubility of 0.40 . This may mean that the test pieces have reached equilibrium with the test solution, and thus we do not expect any further changes.

We also observed that softening occurred more slowly for the samples exposed to solutions with relative solubilities of 0.10 and 0.20 than what we observed previously (Parker and Ranney 1994). This is most likely a result of the pieces being approximately $20 \%$ thicker in this study.

\section{Long-term TCE studies}

Table 5 gives the results of exposure to aqueous solutions of TCE with relative solubilities of $0.05,0.1$, $0.2,0.4$, and 0.6 . The samples exposed to the solutions with relative solubilities of 0.6 and 0.4 had significant changes in their hardness readings; however, they did not become pliable. It should be noted that TCE has never before been shown to be active at such a low relative solubility, and that it took more than a year before significant changes in hardness were detected in those samples. There were also significant changes in the weights of the samples exposed to the solutions with relative solubilities of 0.4 and 0.6 .

It is clear from this and the previous study that small but measurable changes occur in the weight 
Table 5a. Hardness (Barcol) readings of PCE exposed to TCE solutions.

\begin{tabular}{|c|c|c|c|c|c|c|}
\hline \multirow{2}{*}{$\begin{array}{l}\text { Relative } \\
\text { solubility }\end{array}$} & \multicolumn{6}{|c|}{ Contact time, months } \\
\hline & 3 & 6 & 9 & 12 & 15 & 18 \\
\hline 0.00 & 70 & 74 & 77 & 76 & 80 & 80 \\
\hline 0.00 & 72 & 73 & 78 & 77 & 78 & 77 \\
\hline 0.00 & 71 & 74 & 80 & 78 & 79 & 78 \\
\hline 0.00 & 71 & 72 & 77 & 74 & 78 & 79 \\
\hline 0.00 & 71 & 71 & 77 & 75 & 78 & 79 \\
\hline $\bar{X}$ & 71.0 & 72.8 & 77.8 & 76.0 & 78.6 & 78.6 \\
\hline 0.05 & 70 & 73 & 74 & 76 & 78 & 79 \\
\hline 0.05 & 71 & 74 & 75 & 75 & 79 & 78 \\
\hline 0.05 & 71 & 72 & 77 & 75 & 78 & 79 \\
\hline 0.05 & 71 & 72 & 78 & 78 & 79 & 78 \\
\hline 0.05 & 72 & 73 & 79 & 74 & 78 & 78 \\
\hline $\bar{X}$ & 71.0 & 72.8 & 76.6 & 75.6 & 78.4 & 78.4 \\
\hline 0.10 & 70 & 74 & 77 & 76 & 79 & 79 \\
\hline 0.10 & 71 & 74 & 76 & 74 & 76 & 80 \\
\hline 0.10 & 70 & 72 & 73 & 77 & 77 & 78 \\
\hline 0.10 & 71 & 72 & 80 & 78 & 78 & 78 \\
\hline 0.10 & 69 & 73 & 80 & 77 & 78 & 78 \\
\hline $\bar{X}$ & 70.2 & 73.0 & 77.2 & 76.4 & 77.6 & 78.6 \\
\hline 0.20 & 71 & 72 & 75 & 78 & 77 & 77 \\
\hline 0.20 & 71 & 73 & 76 & 74 & 78 & 77 \\
\hline 0.20 & 69 & 73 & 74 & 75 & 79 & 79 \\
\hline 0.20 & 71 & 74 & 79 & 75 & 76 & 79 \\
\hline 0.20 & 72 & 72 & 75 & 74 & 77 & 78 \\
\hline $\bar{X}$ & 70.8 & 72.8 & 75.8 & 75.2 & 77.4 & 78.0 \\
\hline 0.40 & 71 & 72 & 77 & 74 & 77 & 76 \\
\hline 0.40 & 71 & 73 & 75 & 76 & 76 & 78 \\
\hline 0.40 & 71 & 74 & 74 & 75 & 76 & 76 \\
\hline 0.40 & 69 & 72 & 78 & 76 & 74 & 76 \\
\hline 0.40 & 70 & 73 & 73 & 74 & 74 & 78 \\
\hline$\vec{X}$ & 70.4 & 72.8 & 75.4 & 75.0 & $75.4^{*}$ & $76.8^{*}$ \\
\hline 0.60 & 68 & 71 & 75 & 73 & 75 & 76 \\
\hline 0.60 & 70 & 70 & 73 & 72 & 75 & 75 \\
\hline 0.60 & 70 & 71 & 74 & 73 & 74 & 77 \\
\hline 0.60 & 68 & 70 & 75 & 74 & 75 & 75 \\
\hline 0.60 & 69 & 72 & 72 & 75 & 73 & 77 \\
\hline $\bar{X}$ & $69.0^{*}$ & $70.8^{*}$ & $73.8^{*}$ & $73.4^{*}$ & $74.4^{*}$ & $76.0^{*}$ \\
\hline
\end{tabular}

*Significantly different from controls.

and hardness of samples exposed to aqueous solutions of PVC solvents and swelling agents, and that these changes occur at lower relative solubilities than was predicted by Berens.

\section{Studies on aqueous solutions that contain several organic solutes}

\section{Short-term study}

In this study, we exposed PVC to two solutions containing ten organic chemicals that were either a PVC solvent or swelling agent (Table 2). The ten organic chemicals were selected based on published $\chi$ values (Berens 1985, Vonk 1985) and on our own tests, where small pieces of PVC casing were subjected to neat organic chemicals (App. A, Ranney and Parker 1995). The sum of the relative solubilities of the organic chemicals in the two solutions was the same, 0.80 . However, the relative solubility of each analyte varied from 0.02 to 0.15 and the relative solubility of each analyte varied from solution $A$ to solution $B$.

Both solutions caused rapid (within one day) 
Table 5b. Percent weight gain of PVC exposed to TCE solutions.

\begin{tabular}{|c|c|c|c|c|c|c|}
\hline \multirow{2}{*}{$\begin{array}{l}\text { Relative } \\
\text { solubility }\end{array}$} & \multicolumn{6}{|c|}{ Contact time, months } \\
\hline & 3 & 6 & 9 & 12 & 15 & 18 \\
\hline 0.00 & 0.26 & 0.00 & 0.26 & 0.17 & 0.27 & 0.17 \\
\hline 0.00 & 0.23 & 0.25 & 0.25 & 0.21 & 0.17 & 0.25 \\
\hline 0.00 & 0.25 & 0.25 & 0.33 & 0.33 & 0.34 & 0.09 \\
\hline 0.00 & 0.17 & 0.39 & 0.08 & 0.25 & 0.16 & 0.18 \\
\hline 0.00 & 0.26 & 0.35 & 0.33 & 0.16 & 0.08 & 0.33 \\
\hline $\bar{X}$ & $0.23^{\mathrm{a}}$ & $0.25^{\mathrm{a}}$ & $0.25^{\mathrm{a}}$ & $0.22^{\mathrm{a}}$ & $0.20^{\mathrm{a}}$ & $0.20^{\mathrm{a}}$ \\
\hline S.D. & 0.04 & 0.15 & 0.10 & 0.07 & 0.10 & 0.09 \\
\hline 0.05 & 0.25 & 0.25 & 0.25 & 0.17 & 0.36 & 0.16 \\
\hline 0.05 & 0.32 & 0.32 & 0.26 & 0.34 & 0.26 & 0.19 \\
\hline 0.05 & 0.08 & 0.42 & 0.17 & 0.26 & 0.27 & 0.16 \\
\hline 0.05 & 0.18 & 0.33 & 0.17 & 0.33 & 0.26 & 0.34 \\
\hline 0.05 & 0.20 & 0.26 & 0.27 & 0.25 & 0.42 & 0.24 \\
\hline $\bar{X}$ & $0.21^{\mathrm{a}}$ & $0.32^{\mathrm{a}}$ & $0.22^{\mathrm{a}}$ & $0.27^{\mathrm{a}, \mathrm{b}}$ & $0.31^{\mathrm{b}}$ & $0.22^{\mathrm{a}}$ \\
\hline S.D. & 0.09 & 0.07 & 0.05 & 0.07 & 0.07 & 0.07 \\
\hline 0.10 & 0.26 & 0.29 & 0.25 & 0.25 & 0.33 & 0.09 \\
\hline 0.10 & 0.25 & 0.16 & 0.17 & 0.18 & 0.26 & 0.20 \\
\hline 0.10 & 0.18 & 0.29 & 0.34 & 0.27 & 0.35 & 0.16 \\
\hline 0.10 & 0.25 & 0.39 & 0.51 & 0.40 & 0.17 & 0.34 \\
\hline 0.10 & 0.18 & 0.33 & 0.18 & 0.17 & 0.17 & 0.34 \\
\hline $\bar{X}$ & $0.22^{\mathrm{a}}$ & $0.29^{\mathrm{a}}$ & $0.29^{a, b}$ & $0.25^{a, b}$ & $0.26^{a, b}$ & $0.23^{\mathrm{a}}$ \\
\hline S.D. & 0.04 & 0.08 & 0.14 & 0.09 & 0.08 & 0.11 \\
\hline 0.20 & 0.34 & 0.41 & 0.00 & 0.35 & 0.34 & 0.28 \\
\hline 0.20 & 0.35 & 0.24 & 0.27 & 0.24 & 0.42 & 0.25 \\
\hline 0.20 & 0.35 & 0.34 & 0.34 & 0.41 & 0.25 & 0.27 \\
\hline 0.20 & 0.26 & 0.25 & 0.36 & 0.34 & 0.35 & 0.34 \\
\hline 0.20 & 0.34 & 0.25 & 0.17 & 0.41 & 0.18 & 0.34 \\
\hline $\bar{X}$ & $0.33^{\mathrm{b}}$ & $0.30^{\mathrm{a}}$ & $0.23^{\mathrm{a}}$ & $0.35^{\mathrm{b}}$ & $0.31^{a, b}$ & $0.30^{\mathrm{a}, \mathrm{b}}$ \\
\hline S.D. & 0.04 & 0.08 & 0.15 & 0.07 & 0.09 & 0.04 \\
\hline 0.40 & 0.33 & 0.30 & 0.43 & 0.40 & 0.53 & 0.57 \\
\hline 0.40 & 0.33 & 0.41 & 0.42 & 0.44 & 0.44 & 0.33 \\
\hline 0.40 & 0.41 & 0.41 & 0.41 & 0.52 & 0.40 & 0.34 \\
\hline 0.40 & 0.40 & 0.34 & 0.43 & 0.47 & 0.33 & 0.25 \\
\hline 0.40 & 0.32 & 0.27 & 0.29 & 0.59 & 0.54 & 0.34 \\
\hline $\bar{X}$ & $0.36^{\mathrm{b}}$ & $0.35^{\mathrm{a}}$ & $0.40^{\mathrm{b}}$ & $0.49^{c}$ & $0.45^{c}$ & $0.37^{b}$ \\
\hline S.D. & 0.04 & 0.07 & 0.06 & 0.07 & 0.09 & 0.12 \\
\hline 0.60 & 0.75 & 0.65 & 0.66 & 0.94 & 0.86 & 0.83 \\
\hline 0.60 & 0.57 & 0.72 & 0.88 & 0.90 & 0.75 & 0.72 \\
\hline 0.60 & 0.61 & 0.49 & 0.65 & 0.90 & 0.78 & 0.55 \\
\hline 0.60 & 0.60 & 0.43 & 0.74 & 0.78 & 0.82 & 0.63 \\
\hline 0.60 & 0.66 & 0.68 & 0.75 & 0.78 & 0.74 & 0.53 \\
\hline$\vec{X}$ & $0.64^{\mathrm{c}}$ & $0.60^{\mathrm{b}}$ & $0.74^{\mathrm{c}}$ & $0.86^{\mathrm{d}}$ & $0.79^{d}$ & $0.65^{c}$ \\
\hline S.D. & 0.07 & 0.12 & 0.09 & 0.07 & 0.05 & 0.13 \\
\hline
\end{tabular}

S.D. = standard deviation

Values with different letters, taken at the same time, are significantly different.

changes in the hardness readings of PVC, although none of these samples actually became pliable (Table 6). The ability of the solution to soften PVC appears to be correlated with the sum of the relative solubilities of the organic solutes, since the behavior of the two test solutions was between that of a methylene chloride solution (i.e., a solution with a PVC solvent) with a relative solubility of 0.8 and a TCE solution (a solution with a swelling agent) with a relative solubility of 0.8 . There does not appear to be a synergistic effect with this solution, i.e., the ability to soften PVC does not appear to be enhanced beyond a simple cumulative effect.

However, the data (both weight change and hardness values) also show the limitations of us- 
Table 6a. Hardness (Barcol) readings of PVC exposed to aqueous solutions of several organic solutes (shortterm study).

\begin{tabular}{lllll} 
& \multicolumn{4}{c}{ Contact time, hours } \\
\cline { 2 - 5 } Treatment & 8 & 24 & 72 & 168 \\
\hline control & 73 & 77 & 74 & 74 \\
control & 69 & 74 & 71 & 72 \\
control & 67 & 76 & 70 & 69 \\
control & 71 & 77 & 74 & 72 \\
control & 68 & 75 & 70 & 71 \\
$\bar{X}$ & $69.6^{\mathrm{a}}$ & $75.8^{\mathrm{a}}$ & $71.8^{\mathrm{a}}$ & $71.6^{\mathrm{a}}$ \\
solution A & 63 & 69 & 58 & 60 \\
solution A & 64 & 67 & 62 & 64 \\
solution A & 65 & 72 & 62 & 62 \\
solution A & 69 & 70 & 65 & 64 \\
solution A & 64 & 67 & 64 & 60 \\
$\bar{X}$ & $65.0^{\mathrm{b}}$ & $69.0^{\mathrm{b}}$ & $62.2^{\mathrm{b}}$ & $62.0^{\mathrm{c}}$ \\
solution B & 67 & 70 & 63 & 68 \\
solution B & 69 & 71 & 68 & 64 \\
solution B & 71 & 71 & 64 & 66 \\
solution B & 65 & 66 & 69 & 66 \\
solution B & 69 & 68 & 64 & 65 \\
$\bar{X}$ & $68.2^{\mathrm{a}, \mathrm{b}}$ & $69.2^{\mathrm{b}}$ & $65.6^{\mathrm{b}}$ & $65.8^{\mathrm{b}}$ \\
\hline
\end{tabular}

Values with different letters, taken at the same time, are significantly different.

ing this approach (i.e., summing the relative solubilities), since solution $A$ appears to be more aggressive than solution $B$ (Table 6), even though they both have the same cumulative relative solubilities. The reason solution A was more aggressive can be explained by the fact that the sum of the mole fractions of the organic solutes was greater in solution A (Table 2). In addition, the sum of the mole fractions of the four most aggressive chemicals (cyclohexanone, 1,2-dichloroethane, methylene chloride, and nitrobenzene) (App. A, Ranney and Parker 1995) in the test solution was also greater.

\section{Mid-term study}

Test pieces of PVC that were exposed to a TCE solution with a relative solubility of 0.2 were not softened during the course of this study ( 56 days) (Table 7). However, samples exposed to a solution containing TCE with a relative solubility of 0.2 and methylene chloride at a relative solubility of 0.4 were softened after seven days. Again, none of these samples were pliable. This test solution was less aggressive than we (Parker and Ranney 1994) found a methylene chloride solution with a relative solubility of 0.6 (i.e., a solution contain-
Table 6b. Percent weight gain of PVC exposed to aqueous solutions of several organic solutes (shortterm study).

\begin{tabular}{lllll} 
& \multicolumn{4}{c}{ Contact time, hours } \\
\cline { 2 - 5 } Treatment & 8 & 24 & 72 & 168 \\
\hline control & 0.00 & 0.00 & 0.23 & 0.24 \\
control & 0.08 & 0.08 & 0.08 & 0.40 \\
control & 0.15 & 0.25 & 0.08 & 0.43 \\
control & 0.09 & 0.16 & 0.25 & 0.27 \\
control & 0.08 & 0.08 & 0.17 & 0.42 \\
$\bar{X}$ & $0.08^{\mathrm{a}}$ & $0.11^{\mathrm{a}}$ & $0.16^{\mathrm{a}}$ & $0.35^{\mathrm{a}}$ \\
S.D. & 0.05 & 0.09 & 0.08 & 0.09 \\
& & & & \\
solution A & 1.23 & 2.35 & 3.36 & 5.58 \\
solution A & 1.07 & 2.57 & 3.58 & 5.29 \\
solution A & 1.03 & 2.48 & 3.90 & 5.29 \\
solution A & 1.08 & 2.34 & 3.61 & 5.00 \\
solution A & 1.07 & 2.36 & 3.70 & 5.67 \\
$\bar{X}$ & $1.10^{\mathrm{c}}$ & $2.42^{\mathrm{c}}$ & $3.63^{\mathrm{c}}$ & $5.37^{\mathrm{c}}$ \\
S.D. & 0.08 & 0.10 & 0.19 & 0.27 \\
& & & & \\
solution B & 0.65 & 1.65 & 2.55 & 3.44 \\
solution B & 0.79 & 1.59 & 2.27 & 3.54 \\
solution B & 0.82 & 1.58 & 2.62 & 3.74 \\
solution B & 0.73 & 1.73 & 2.36 & 3.53 \\
solution B & 0.78 & 1.42 & 2.60 & 4.20 \\
$\bar{X}$ & $0.75^{\mathrm{b}}$ & $1.59^{\mathrm{b}}$ & $2.48^{\mathrm{b}}$ & $3.69 \mathrm{~b}$ \\
S.D. & 0.07 & 0.11 & 0.16 & 0.31 \\
\hline
\end{tabular}

S.D. = standard deviation

Values with different letters, taken at the same time, are sigificantly different.

ing a PVC solvent) to be, but more aggressive than we (Parker and Ranney 1994) found a TCE solution with the same relative solubility $(0.6)$ to be. Thus, there does not appear to be an enhanced or synergistic effect of the organic solutes in this test solution, and taking the sum of the relative solubilities was useful in roughly predicting the ability of this test solution to soften PVC.

\section{First long-term study}

PVC pieces were exposed to two aqueous solutions that contained 18 organic chemicals that were either a PVC solvent or swelling agent (Table 8). In these solutions, the relative solubility of each chemical was either 0.01 or 0.02 , and the sums of the relative solubilities of all the organic solutes in the test solutions were 0.18 and 0.36 , respectively. After 40 weeks' exposure, the test pieces exposed to the test solution with the higher total relative solubility $(0.36)$ had significant changes in hardness readings (but were not pliable), while those exposed to the solution with the lower total relative solubility $(0.18)$ did not. However, there was a significant increase in the weight of the test pieces exposed to this test solution when compared with the controls. 
Table 7a. Hardness (Barcol) readings of PVC exposed to aqueous solutions of methylene chloride (MC) and TCE.

\begin{tabular}{|c|c|c|c|c|c|c|}
\hline \multirow{2}{*}{\multicolumn{2}{|c|}{$\begin{array}{l}\text { Relative } \\
\text { solubility } \\
M C, T C E\end{array}$}} & \multicolumn{4}{|c|}{ Contact time, days } & \multirow[b]{2}{*}{56} \\
\hline & & 2 & 7 & 14 & 28 & \\
\hline \multicolumn{2}{|c|}{ control } & 75 & 70 & 73 & 79 & 76 \\
\hline \multicolumn{2}{|c|}{ control } & 73 & 71 & 74 & 76 & 74 \\
\hline \multicolumn{2}{|c|}{ control } & 74 & 73 & 75 & 78 & 75 \\
\hline \multicolumn{2}{|c|}{ control } & 73 & 74 & 72 & 77 & 75 \\
\hline \multicolumn{2}{|c|}{ control } & 76 & 75 & 73 & 76 & 77 \\
\hline \multicolumn{2}{|l|}{$\bar{X}$} & 74.2 & 72.6 & 73.4 & 77.2 & 75.4 \\
\hline 0, & 0.2 & 72 & 73 & 74 & 78 & 76 \\
\hline 0 & 0.2 & 74 & 75 & 73 & 77 & 75 \\
\hline 0 & 0.2 & 75 & 74 & 71 & 72 & 74 \\
\hline 0, & 0.2 & 74 & 72 & 70 & 76 & 75 \\
\hline 0, & 0.2 & 73 & 71 & 72 & 78 & 74 \\
\hline \multicolumn{2}{|c|}{$\bar{X}$} & 73.6 & 73.0 & 72.0 & 76.2 & 74.8 \\
\hline 0 , & 0.4 & 74 & 69 & 74 & 74 & 76 \\
\hline 0 & 0.4 & 73 & 70 & 74 & 78 & 75 \\
\hline 0 & 0.4 & 74 & 73 & 74 & 78 & 75 \\
\hline 0 & 0.4 & 74 & 71 & 73 & 73 & 73 \\
\hline & 0.4 & 73 & 72 & 70 & 78 & 75 \\
\hline \multicolumn{2}{|c|}{$\bar{X}$} & 73.6 & 71.0 & 73.0 & 76.2 & 74.8 \\
\hline 0 & 0.6 & 73 & 73 & 72 & 77 & 74 \\
\hline & 0.6 & 75 & 71 & 73 & 75 & 75 \\
\hline 0 & 0.6 & 76 & 72 & 68 & 79 & 74 \\
\hline 0 & 0.6 & 74 & 68 & 70 & 78 & 73 \\
\hline 0 & 0.6 & 75 & 71 & 73 & 77 & 74 \\
\hline \multicolumn{2}{|c|}{$\bar{X}$} & 74.6 & 71.0 & 71.2 & 77.2 & $74.0 \times$ \\
\hline 0.4 & 0 & 76 & 68 & 75 & 74 & 74 \\
\hline 0.4 & 0 & 72 & 72 & 70 & 78 & 73 \\
\hline 0.4 & 0 & 74 & 73 & 71 & 76 & 72 \\
\hline 0.4 & 0 & 73 & 71 & 69 & 78 & 73 \\
\hline 0.4 & 0 & 75 & 71 & 72 & 73 & 72 \\
\hline \multicolumn{2}{|c|}{$\bar{X}$} & 74.0 & 71.0 & 71.4 & 75.8 & $72.8^{*}$ \\
\hline 0.4 & 0.2 & 73 & 66 & 70 & 74 & 72 \\
\hline 0.4 & 0.2 & 76 & 67 & 69 & 73 & 70 \\
\hline 0.4 & 0.2 & 74 & 66 & 72 & 75 & 72 \\
\hline 0.4 & 0.2 & 75 & 66 & 70 & 72 & 71 \\
\hline 0.4 & 0.2 & 72 & 69 & 72 & 74 & 72 \\
\hline \multicolumn{2}{|c|}{$\bar{X}$} & 74.0 & $66.8^{*}$ & $70.6^{*}$ & $73.6^{*}$ & $71.4^{x}$ \\
\hline 0.4 & 0.4 & 73 & 70 & 70 & 73 & 70 \\
\hline 0.4 & 0.4 & 71 & 71 & 68 & 71 & 70 \\
\hline 0.4 & 0.4 & 74 & 68 & 68 & 74 & 68 \\
\hline 0.4 & 0.4 & 73 & 65 & 71 & 75 & 70 \\
\hline 0.4 & 0.4 & 74 & 66 & 69 & 70 & 69 \\
\hline \multicolumn{2}{|c|}{$\bar{X}$} & 73.0 & $68.0^{*}$ & $69.2^{*}$ & $72.6^{*}$ & $69.4^{*}$ \\
\hline & 0.6 & 66 & 63 & 60 & 67 & 62 \\
\hline 0.4 & 0.6 & 70 & 64 & 63 & 63 & 62 \\
\hline 0.4 & 0.6 & 70 & 65 & 65 & 70 & 65 \\
\hline 0.4 & 0.6 & 68 & 65 & 64 & 64 & 61 \\
\hline 0.4 , & 0.6 & 71 & 67 & 61 & 62 & 63 \\
\hline \multicolumn{2}{|c|}{$\bar{X}$} & $69.0^{*}$ & $64.8^{*}$ & $62.6^{*}$ & $65.2^{*}$ & $62.6^{\prime}$ \\
\hline
\end{tabular}

*Significantly different from controls.
Table 7b. Percent weight gain of PVC exposed to aqueous solutions of methylene chloride $(\mathrm{MC})$ and TCE.

Relative

solubility MC, TCE

\begin{tabular}{|c|c|c|c|c|c|}
\hline control & 0.08 & 0.16 & 0.16 & 0.00 & 0.25 \\
\hline control & 0.08 & 0.08 & 0.08 & 0.16 & 0.17 \\
\hline control & 0.40 & 0.17 & 0.08 & 0.17 & 0.09 \\
\hline control & 0.00 & 0.17 & 0.09 & 0.25 & 0.1 \\
\hline control & 0.09 & 0.16 & 0.00 & 0.16 & 0.1 \\
\hline $\bar{X}$ & $0.13^{a}$ & $0.15^{a}$ & $0.08^{a}$ & $0.15^{\mathrm{a}}$ & 0.1 \\
\hline S.D. & 0.15 & 0.04 & 0.06 & 0.09 & 0.06 \\
\hline 0.2 & 0.08 & 0.25 & 0.24 & 0.24 & 0.27 \\
\hline 0.2 & 0.08 & 0.16 & 0.25 & 0.24 & 0. \\
\hline 0.2 & 0.00 & 0.23 & 0.08 & 0.08 & 0.2 \\
\hline 0.2 & 0.00 & 0.26 & 0.24 & 0.24 & 0.24 \\
\hline 0.2 & 0.00 & 0.16 & 0.16 & 0.16 & 0.1 \\
\hline $\bar{X}$ & $0.03^{\mathrm{a}}$ & $0.21^{\mathrm{a}}$ & $0.19^{a}$ & $0.19^{\mathrm{a}}$ & 0.2 \\
\hline S.D. & 0.04 & 0.05 & 0.08 & 0.07 & 0.03 \\
\hline
\end{tabular}

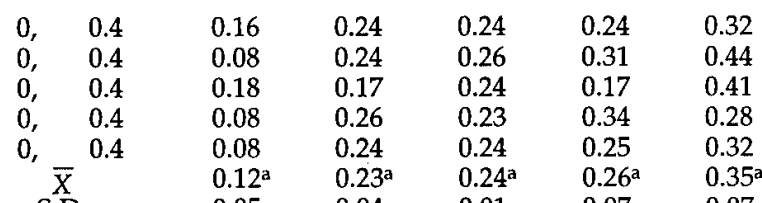
$\begin{array}{llllll}\text { S.D. } & 0.05 & 0.04 & 0.01 & 0.07 & 0.07\end{array}$

$\begin{array}{lllllll}0, & 0.6 & 0.16 & 0.40 & 0.44 & 0.41 & 0.32\end{array}$

$\begin{array}{lllllll}0, & 0.6 & 0.17 & 0.47 & 0.46 & 0.49 & 0.50 \\ 0, & 0.6 & 0.16 & 0.34 & 0.49 & 0.46 & 0.32\end{array}$

$\begin{array}{lllllll}0, & 0.6 & 0.16 & 0.34 & 0.49 & 0.46 & 0.32 \\ 0, & 0.6 & 0.17 & 0.25 & 0.37 & 0.48 & 0.32\end{array}$

$0,{ }_{\bar{X}} \begin{array}{llllll}0.6 & 0.00 & 0.33 & 0.48 & 0.42 & 0.49\end{array}$

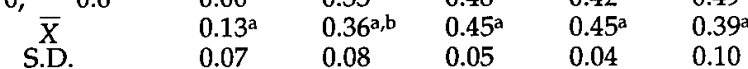

$\begin{array}{lllllll}0.4 & 0 & 0.37 & 0.59 & 0.81 & 1.12 & 1.26\end{array}$

$\begin{array}{lllllll}0.4, & 0 & 0.33 & 0.74 & 0.84 & 0.93 & 1.42\end{array}$

$\begin{array}{lllllll}0.4, & 0 & 0.24 & 0.73 & 0.99 & 1.06 & 1.18\end{array}$

$\begin{array}{lllllll}0.4, & 0 & 0.43 & 0.56 & 0.91 & 1.15 & 1.23\end{array}$

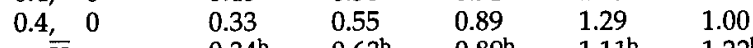

$\begin{array}{llllll}\bar{X} & 0.34^{\mathrm{b}} & 0.63^{\mathrm{b}} & 0.89^{\mathrm{b}} & 1.11^{\mathrm{b}} & 1.22^{\mathrm{b}} \\ \text { S.D. } & 0.07 & 0.09 & 0.07 & 0.13 & 0.15\end{array}$

$\begin{array}{lllllll}0.4, & 0.2 & 0.56 & 0.83 & 1.31 & 1.03 & 1.55\end{array}$

$\begin{array}{lllllll}0.4, & 0.2 & 0.56 & 1.01 & 1.09 & 1.42 & 1.90\end{array}$

$\begin{array}{lllllll}0.4, & 0.2 & 0.49 & 1.05 & 1.26 & 1.71 & 1.69\end{array}$

$\begin{array}{lllllll}0.4, & 0.2 & 0.51 & 1.02 & 1.22 & 1.53 & 1.62\end{array}$

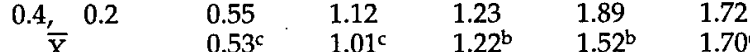

$\begin{array}{llllll}\bar{X} & 0.53^{\mathrm{c}} & 1.01^{\mathrm{c}} & 1.22^{\mathrm{b}} & 1.52^{\mathrm{b}} & 1.70^{\mathrm{c}} \\ \text { S.D. } & 0.03 & 0.11 & 0.08 & 0.32 & 0.13\end{array}$

$\begin{array}{lllllll}0.4, & 0.4 & 1.04 & 1.91 & 2.11 & 1.79 & 3.19\end{array}$

$\begin{array}{lllllll}0.4, & 0.4 & 0.89 & 1.80 & 2.18 & 2.63 & 2.80 \\ 0.4 & 0.4 & 0.97 & 1.80 & 1.86 & 3.36 & 254\end{array}$

$\begin{array}{lllllll}0.4, & 0.4 & 0.83 & 1.85 & 2.09 & 2.98 & 2.22\end{array}$

$\begin{array}{lllllll}0.4, & 0.4 & 0.49 & 1.74 & 2.21 & 3.12 & 2.38\end{array}$

$\begin{array}{llllll}\bar{X} & 0.84^{\mathrm{d}} & 1.82^{\mathrm{d}} & 2.09^{\mathrm{c}} & 2.78^{\mathrm{d}} & 2.63^{\mathrm{d}} \\ \text { S.D. } & 0.21 & 0.07 & 0.14 & 0.61 & 0.38\end{array}$

$\begin{array}{lllllll}0.4, & 0.6 & 2.72 & 5.02 & 6.88 & 4.49 & 5.78\end{array}$

$\begin{array}{lllllll}0.4, & 0.6 & 2.35 & 3.80 & 5.05 & 5.07 & 5.48\end{array}$

\begin{tabular}{lllllll}
0.4, & 0.6 & 2.50 & 5.06 & 5.24 & 5.24 & 5.21 \\
\hline
\end{tabular}

$\begin{array}{lllllll}0.4, & 0.6 & 2.18 & 5.37 & 4.92 & 5.81 & 5.48 \\ 0.4, & 0.6 & 2.36 & 4.05 & 5.67 & 5.97 & 5.25\end{array}$

$\begin{array}{clllll}0.4{ }_{\bar{X}} 0.6 & 2.36 & 4.05 & 5.67 & 5.97 & 5.25 \\ & 2.42^{\mathrm{e}} & 4.66^{\mathrm{e}} & 5.55^{\mathrm{d}} & 5.32^{\mathrm{d}} & 5.44^{\mathrm{e}}\end{array}$

\begin{tabular}{llllll} 
S.D. & 0.20 & 0.69 & 0.80 & 0.60 & 0.23 \\
\hline
\end{tabular}

S.D. = standard deviation

Values with different letters, taken at the same time, are significantly different. 
Table 8. Hardness (Barcol) readings and percent weight gain of PVC exposed to aqueous solutions of several organic solutes (first long-term study).

\begin{tabular}{cccccc} 
Relative & \multicolumn{2}{c}{20 week } & & \multicolumn{2}{c}{40 week } \\
\cline { 2 - 3 } \cline { 5 - 6 } solubility & Barcol & $\% \Delta$ weight & & Barcol & $\% \Delta$ weight \\
\hline control & 78 & 0.40 & & 76 & 0.41 \\
control & 77 & 0.37 & & 74 & 0.47 \\
control & 74 & 0.53 & & 76 & 0.40 \\
control & 76 & 0.41 & & 74 & 0.41 \\
control & 77 & 0.36 & & 76 & 0.37 \\
$\bar{X}$ & $76.4^{\mathrm{a}}$ & $0.41^{\mathrm{a}}$ & & $75.2^{\mathrm{a}}$ & $0.41^{\mathrm{a}}$ \\
S.D. & & 0.07 & & & 0.04 \\
0.01 & 74 & 0.59 & & 75 & 0.54 \\
0.01 & 74 & 0.50 & & 74 & 0.64 \\
0.01 & 76 & 0.61 & & 75 & 0.70 \\
0.01 & 76 & 0.56 & & 74 & 0.36 \\
0.01 & 77 & 0.47 & & 73 & 0.52 \\
$\bar{X}$ & $75.4^{\mathrm{a}}$ & $0.55^{\mathrm{b}}$ & & $74.2^{\mathrm{a}} \mathrm{b}$ & $0.55^{\mathrm{b}}$ \\
S.D. & & 0.06 & & 0.13 \\
0.02 & 76 & 0.92 & & 72 & 0.93 \\
0.02 & 74 & 0.65 & & 75 & 0.99 \\
0.02 & 77 & 0.91 & 74 & 0.93 \\
0.02 & 76 & 0.75 & 73 & 0.80 \\
0.02 & 72 & 0.68 & 72 & 0.92 \\
$\bar{X}$ & $75.0^{\mathrm{a}}$ & $0.78^{\mathrm{c}}$ & $73.2^{\mathrm{b}}$ & $0.91^{\mathrm{c}}$ \\
S.D. & & 0.13 & & 0.07 \\
\hline
\end{tabular}

S.D. = standard deviation

Values with different letters, taken at the same time, are significantly different.
Second long-term study

Table 9 gives the results of exposing PVC to a test solution containing the same eighteen organic solutes at four different relative solubilities for up to 18 months. The relative solubility of each of the organic solutes was either $0.001,0.005,0.010$, or 0.020 . Thus, the sums of the relative solubilities of the organic solutes in these solutions were 0.018 , $0.090,0.18$, and 0.36 , respectively.

The test results show that when the sum of the relative solubilities of the organic solutes in the test solutions was less than 0.10 , softening did not occur. Test pieces that were exposed to organic solutes with relative solubilities of 0.010 and 0.020 (or cumulative relative solubilities of 0.18 and 0.36 ) had hardness readings that were significantly lower than the controls but were not rubbery. These results agree with our previous findings for methylene chloride, i.e., softening does not occur when the relative solubility of the analyte in the test solution is less than 0.1. The weight gain data also support these conclusions. Significant changes in weight were found in samples exposed to solutions with relative solubilities of 0.01 and 0.02 . Generally, there was not significant change in the weights of samples exposed to solutions with lower relative solubilities.

Table 9a. Hardness (Barcol) readings of PVC exposed to aqueous solutions of several organic solutes (second long-term study).

\begin{tabular}{cllllll} 
Relative & \multicolumn{5}{c}{ Contact time, months } \\
\cline { 2 - 7 } solubility & 3 & 6 & 9 & 12 & 15 & 18 \\
\hline control & 71 & 74 & 77 & 79 & 79 & 79 \\
control & 72 & 75 & 76 & 78 & 77 & 80 \\
control & 73 & 73 & 75 & 76 & 77 & 78 \\
control & 72 & 74 & 79 & 77 & 78 & 78 \\
control & 73 & 75 & 77 & 77 & 79 & 78 \\
$\bar{X}$ & 72.2 & 74.2 & 76.8 & 77.4 & 78.0 & 78.6 \\
0.001 & 71 & 74 & 77 & 78 & 77 & 78 \\
0.001 & 73 & 75 & 76 & 77 & 79 & 78 \\
0.001 & 71 & 74 & 75 & 76 & 80 & 79 \\
0.001 & 72 & 75 & 75 & 77 & 78 & 77 \\
0.001 & 73 & 73 & 76 & 77 & 78 & 78 \\
$\bar{X}$ & 72.0 & 74.2 & 75.8 & 77.0 & 78.4 & 78.0 \\
0.005 & 71 & 74 & 77 & 75 & 77 & 79 \\
0.005 & 72 & 75 & 73 & 77 & 78 & 78 \\
0.005 & 73 & 73 & 74 & 78 & 79 & 78 \\
0.005 & 72 & 74 & 75 & 76 & 77 & 77 \\
0.005 & 72 & 75 & 77 & 77 & 76 & 79 \\
$\bar{X}$ & 72.0 & 74.2 & 75.2 & 76.6 & 77.4 & 78.2 \\
0.01 & 71 & 74 & 75 & 76 & 77 & 77 \\
0.01 & 71 & 74 & 75 & 76 & 78 & 77 \\
0.01 & 72 & 74 & 73 & 78 & 78 & 78 \\
0.01 & 72 & 75 & 75 & 77 & 76 & 77 \\
0.01 & 71 & 73 & 76 & 75 & 77 & 75 \\
$\bar{X}$ & 71.4 & 74.0 & $74.8^{*}$ & 76.4 & 77.2 & $76.8^{*}$
\end{tabular}


Table 9a (cont'd).

\begin{tabular}{ccccccc} 
Relative & \multicolumn{7}{c}{ Contact time, months } \\
\cline { 2 - 7 } solubility & 3 & 6 & 9 & 12 & 15 & 18 \\
\hline 0.02 & 72 & 74 & 74 & 73 & 76 & 75 \\
0.02 & 70 & 73 & 74 & 75 & 75 & 76 \\
0.02 & 71 & 74 & 75 & 76 & 77 & 74 \\
0.02 & 72 & 73 & 75 & 76 & 77 & 76 \\
0.02 & 72 & 73 & 73 & 75 & 75 & 74 \\
$\bar{X}$ & 71.4 & 73.4 & $74.2^{*}$ & $75.0^{*}$ & $76.0^{*}$ & $75.0^{*}$ \\
\hline
\end{tabular}

*Significantly different from controls.

Table 9b. Percent weight gain of PVC exposed to aqueous solutions of several organic solutes (second long-term study).

\begin{tabular}{|c|c|c|c|c|c|c|}
\hline \multirow{2}{*}{$\begin{array}{l}\text { Relative } \\
\text { solubility }\end{array}$} & \multicolumn{5}{|c|}{ Contact time, months } & \multirow[b]{2}{*}{18} \\
\hline & 3 & 6 & 9 & 12 & 15 & \\
\hline control & 0.17 & 0.32 & 0.27 & 0.08 & 0.24 & 0.24 \\
\hline control & 0.13 & 0.25 & 0.17 & 0.35 & 0.25 & 0.09 \\
\hline control & 0.16 & 0.17 & 0.09 & 0.41 & 0.17 & 0.13 \\
\hline control & 0.25 & 0.26 & 0.09 & 0.34 & 0.20 & 0.17 \\
\hline control & 0.17 & 0.34 & 0.16 & 0.16 & 0.17 & 0.26 \\
\hline$\overline{\mathrm{X}}$ & $0.18^{\mathrm{a}}$ & $0.27^{a}$ & $0.16^{a}$ & $0.27^{\mathrm{a}}$ & $0.21^{\mathrm{a}}$ & $0.18^{\mathrm{a}}$ \\
\hline S.D. & 0.04 & 0.07 & 0.07 & 0.14 & 0.04 & 0.07 \\
\hline 0.001 & 0.17 & 0.25 & 0.13 & 0.26 & 0.18 & 0.18 \\
\hline 0.001 & 0.26 & 0.17 & 0.17 & 0.24 & 0.33 & 0.27 \\
\hline 0.001 & 0.16 & 0.33 & 0.17 & 0.34 & 0.25 & 0.16 \\
\hline 0.001 & 0.17 & 0.26 & 0.32 & 0.24 & 0.25 & 0.38 \\
\hline 0.001 & 0.27 & 0.34 & 0.17 & 0.33 & 0.20 & 0.07 \\
\hline $\bar{X}$ & $0.21^{\mathrm{a}}$ & $0.27^{a}$ & $0.19^{\mathrm{a}}$ & $0.28^{a}$ & $0.24^{\mathrm{a}}$ & $0.21^{\mathrm{a}}$ \\
\hline S.D. & 0.05 & 0.07 & 0.07 & 0.05 & 0.06 & 0.12 \\
\hline 0.005 & 0.34 & 0.33 & 0.44 & 0.35 & 0.41 & 0.27 \\
\hline 0.005 & 0.34 & 0.62 & 0.17 & 0.17 & 0.40 & 0.16 \\
\hline 0.005 & 0.33 & 0.25 & 0.25 & 0.25 & 0.26 & 0.18 \\
\hline 0.005 & 0.33 & 0.25 & 0.17 & 0.34 & 0.34 & 0.17 \\
\hline 0.005 & 0.45 & 0.42 & 0.14 & 0.17 & 0.40 & 0.33 \\
\hline$\overline{\mathrm{X}}$ & $0.36^{\mathrm{b}}$ & $0.37^{a, b}$ & $0.23^{a, b}$ & $0.26^{\mathrm{a}}$ & $0.36^{\mathrm{b}}$ & $0.22^{\mathrm{a}}$ \\
\hline S.D. & 0.05 & 0.15 & 0.12 & 0.09 & 0.06 & 0.08 \\
\hline 0.01 & 0.33 & 0.57 & 0.46 & 0.41 & 0.51 & 0.42 \\
\hline 0.01 & 0.33 & 0.51 & 0.31 & 0.53 & 0.52 & 0.42 \\
\hline 0.01 & 0.24 & 0.33 & 0.27 & 0.71 & 0.59 & 0.47 \\
\hline 0.01 & 0.28 & 0.52 & 0.43 & 0.62 & 0.62 & 0.33 \\
\hline 0.01 & 0.32 & 0.43 & 0.20 & 0.41 & 0.52 & 0.21 \\
\hline $\bar{X}$ & $0.30^{\mathrm{b}}$ & $0.47^{\mathrm{b}}$ & $0.33^{b}$ & $0.54^{\mathrm{b}}$ & $0.55^{c}$ & $0.37^{\mathrm{b}}$ \\
\hline S.D. & 0.04 & 0.09 & 0.11 & 0.13 & 0.05 & 0.10 \\
\hline 0.02 & 0.57 & 0.64 & 0.66 & 0.84 & 0.73 & 0.88 \\
\hline 0.02 & 0.57 & 0.75 & 0.67 & 0.82 & 0.87 & 0.70 \\
\hline 0.02 & 0.35 & 0.63 & 0.68 & 0.92 & 0.68 & 1.01 \\
\hline 0.02 & 0.59 & 0.58 & 0.44 & 0.80 & 0.74 & 0.63 \\
\hline 0.02 & 0.54 & 0.73 & 0.64 & 0.91 & 0.84 & 0.78 \\
\hline $\bar{X}$ & $0.52^{c}$ & $0.67^{c}$ & $0.62^{c}$ & $0.86^{c}$ & $0.77^{\mathrm{d}}$ & $0.80^{c}$ \\
\hline S.D. & 0.10 & 0.07 & 0.10 & 0.05 & 0.08 & 0.15 \\
\hline
\end{tabular}

S.D. = standard deviation

Values with different letters, taken at the same time, are significantly different. 
Table 10a. Hardness (Barcol) readings of PVC exposed to acetone solutions.

\begin{tabular}{cllllll} 
& \multicolumn{5}{c}{ Contact time, months } \\
\cline { 2 - 7 } Concentration (\%) & 3 & 6 & 9 & 12 & 15 & 18 \\
\hline control & 73 & 74 & 80 & 77 & 79 & 81 \\
control & 71 & 74 & 79 & 76 & 77 & 78 \\
control & 72 & 73 & 77 & 77 & 78 & 78 \\
control & 71 & 72 & 78 & 78 & 78 & 79 \\
control & 72 & 74 & 77 & 79 & 78 & 80 \\
$\bar{X}$ & 71.8 & 73.4 & 78.2 & 77.4 & 78.0 & 79.2 \\
0.5 & 71 & 74 & 78 & 77 & 77 & 78 \\
0.5 & 72 & 75 & 80 & 78 & 78 & 76 \\
0.5 & 72 & 73 & 77 & 76 & 78 & 79 \\
0.5 & 71 & 73 & 79 & 77 & 77 & 79 \\
0.5 & 71 & 72 & 76 & 77 & 79 & 80 \\
$\bar{X}$ & 71.4 & 73.4 & 78.0 & 77.0 & 77.8 & 78.4 \\
1.0 & 71 & 73 & 78 & 77 & 78 & 78 \\
1.0 & 71 & 74 & 77 & 76 & 79 & 79 \\
1.0 & 70 & 74 & 78 & 78 & 77 & 79 \\
1.0 & 71 & 72 & 78 & 76 & 77 & 78 \\
1.0 & 72 & 73 & 78 & 77 & 78 & 78 \\
$\bar{X}$ & 71.0 & 73.2 & 77.8 & 76.8 & 77.8 & 78.4 \\
5.0 & 71 & 73 & 79 & 76 & 76 & 77 \\
5.0 & 72 & 72 & 78 & 76 & 76 & 78 \\
5.0 & 70 & 72 & 79 & 78 & 76 & 77 \\
5.0 & 71 & 73 & 78 & 77 & 77 & 76 \\
5.0 & 71 & 74 & 74 & 76 & 75 & 76 \\
$\bar{X}$ & 71.0 & 72.8 & 77.6 & 76.6 & $76.0^{*}$ & $76.8^{*}$ \\
10.0 & 71 & 71 & 76 & 76 & 75 & 75 \\
10.0 & 71 & 73 & 75 & 74 & 74 & 75 \\
10.0 & 72 & 72 & 74 & 74 & 75 & 77 \\
10.0 & 70 & 71 & 76 & 73 & 74 & 76 \\
10.0 & 71 & 73 & 75 & 75 & 73 & 76 \\
$\bar{X}$ & 71.0 & $72.0^{*}$ & $75.2^{*}$ & $74.4^{*}$ & $74.2^{*}$ & $75.8^{*}$ \\
$\bar{X}$ & 69 & 71 & 69 & 74 & 72 & 72 \\
20.0 & 71 & 73 & 73 & 72 & 69 & 71 \\
20.0 & 70 & 72 & 73 & 73 & 72 & 71 \\
20.0 & 69 & 71 & 71 & 70 & 69 & 70 \\
20.0 & 71 & 72 & 72 & 71 & 68 & 70 \\
\hline & $70.0^{*}$ & $71.8^{*}$ & $71.6^{*}$ & $72.0^{*}$ & $70.0^{*}$ & $70.8^{*}$ \\
\hline & & & & & &
\end{tabular}

*Significantly different from controls.

The results from the first long-term study compare well with these findings. In the previous experiment the Teflon-lined caps were lined with aluminum foil to prevent substantial losses of the organic solutes due to sorption by the Teflon liners. In this experiment there was no aluminum liner. Thus, we concluded that the Teflon does not appear to substantially alter the ability of the test solutions to affect PVC.
Studies on aqueous solutions containing organics that are miscible in water

Long-term acetone study

Table 10 shows the results of long-term (18 months) exposure to $0.5 \%, 1.0 \%, 5.0 \%, 10 \%$, and $20 \%$ solutions of acetone. By the end of the study, the $5.0 \%, 10 \%$, and $20 \%$ solutions were able to 
Table 10b. Percent weight gain of PVC exposed to acetone solutions.

\begin{tabular}{|c|c|c|c|c|c|c|}
\hline \multirow[b]{2}{*}{ Concentration (\%) } & \multicolumn{6}{|c|}{ Contact time, months } \\
\hline & 3 & 6 & 9 & 12 & 15 & 18 \\
\hline 0.0 & 0.17 & 0.26 & 0.28 & 0.36 & 0.24 & 0.17 \\
\hline 0.0 & 0.13 & 0.18 & 0.27 & 0.25 & 0.26 & 0.09 \\
\hline 0.0 & 0.17 & 0.24 & 0.22 & 0.17 & 0.09 & 0.17 \\
\hline 0.0 & 0.17 & 0.18 & 0.26 & 0.16 & 0.25 & 0.08 \\
\hline 0.0 & 0.16 & 0.08 & 0.26 & 0.33 & 0.35 & 0.14 \\
\hline $\bar{X}$ & $0.16^{\mathrm{a}}$ & $0.19^{a}$ & $0.26^{\mathrm{a}}$ & $0.25^{\mathrm{a}}$ & $0.24^{\mathrm{a}}$ & $0.13^{a}$ \\
\hline S.D. & 0.02 & 0.07 & 0.02 & 0.09 & 0.09 & 0.04 \\
\hline 0.5 & 0.17 & 0.27 & 0.33 & 0.31 & 0.34 & 0.34 \\
\hline 0.5 & 0.13 & 0.34 & 0.25 & 0.27 & 0.25 & 0.22 \\
\hline 0.5 & 0.13 & 0.24 & 0.24 & 0.40 & 0.26 & 0.08 \\
\hline 0.5 & 0.17 & 0.24 & 0.17 & 0.28 & 0.25 & 0.25 \\
\hline 0.5 & 0.17 & 0.25 & 0.27 & 0.35 & 0.31 & 0.33 \\
\hline $\bar{X}$ & $0.15^{\mathrm{a}}$ & $0.27^{a}$ & $0.25^{\mathrm{a}}$ & $0.32^{\mathrm{a}, \mathrm{b}}$ & $0.28^{a}$ & $0.24^{a, b}$ \\
\hline S.D. & 0.02 & 0.04 & 0.06 & 0.06 & 0.04 & 0.10 \\
\hline 1.0 & 0.26 & 0.32 & 0.33 & 0.33 & 0.26 & 0.27 \\
\hline 1.0 & 0.15 & 0.25 & 0.33 & 0.26 & 0.27 & 0.18 \\
\hline 1.0 & 0.27 & 0.25 & 0.27 & 0.26 & 0.24 & 0.27 \\
\hline 1.0 & 0.26 & 0.25 & 0.25 & 0.27 & 0.25 & 0.20 \\
\hline 1.0 & 0.27 & 0.25 & 0.24 & 0.26 & 0.25 & 0.18 \\
\hline $\bar{X}$ & $0.24^{\mathrm{b}}$ & $0.26^{\mathrm{a}}$ & $0.28^{\mathrm{a}}$ & $0.28^{\mathrm{a}}$ & $0.25^{\mathrm{a}}$ & $0.22^{\mathrm{a}, \mathrm{b}}$ \\
\hline S.D. & 0.05 & 0.03 & 0.04 & 0.03 & 0.01 & 0.05 \\
\hline 5.0 & 0.18 & 0.45 & 0.42 & 0.36 & 0.35 & 0.33 \\
\hline 5.0 & 0.16 & 0.26 & 0.33 & 0.44 & 0.32 & 0.32 \\
\hline 5.0 & 0.25 & 0.33 & 0.41 & 0.40 & 0.26 & 0.35 \\
\hline 5.0 & 0.27 & 0.25 & 0.27 & 0.49 & 0.25 & 0.34 \\
\hline 5.0 & 0.21 & 0.17 & 0.43 & 0.44 & 0.34 & 0.25 \\
\hline $\bar{X}$ & $0.21^{\mathrm{b}}$ & $0.29^{a}$ & $0.37^{b}$ & $0.43^{b, c}$ & $0.30^{\mathrm{a}}$ & $0.32^{\mathrm{b}}$ \\
\hline S.D. & 0.04 & 0.10 & 0.07 & 0.05 & 0.05 & 0.04 \\
\hline 10 & 0.33 & 0.50 & 0.49 & 0.49 & 0.51 & 0.52 \\
\hline 10 & 0.36 & 0.36 & 0.66 & 0.45 & 0.44 & 0.45 \\
\hline 10 & 0.26 & 0.49 & 0.64 & 0.70 & 0.42 & 0.51 \\
\hline 10 & 0.25 & 0.60 & 0.46 & 0.45 & 0.50 & 0.53 \\
\hline 10 & 0.34 & 0.46 & 0.40 & 0.43 & 0.27 & 0.40 \\
\hline $\bar{x}$ & $0.31^{\mathrm{c}}$ & $0.48^{b}$ & $0.53^{c}$ & $0.50^{c}$ & $0.43^{b}$ & $0.48^{\mathrm{c}}$ \\
\hline S.D. & 0.05 & 0.09 & 0.11 & 0.11 & 0.10 & 0.06 \\
\hline 20 & 1.08 & 1.39 & 1.68 & 1.95 & 1.90 & 1.86 \\
\hline 20 & 1.10 & 1.45 & 1.68 & 1.66 & 1.95 & 1.98 \\
\hline 20 & 1.16 & 1.14 & 1.69 & 1.45 & 1.75 & 1.95 \\
\hline 20 & 1.10 & 1.37 & 1.64 & 1.81 & 1.52 & 2.03 \\
\hline 20 & 1.07 & 1.25 & 1.77 & 1.81 & 1.86 & 1.52 \\
\hline $\bar{X}$ & $1.10^{d}$ & $1.32^{c}$ & $1.69^{d}$ & $1.74^{\mathrm{d}}$ & $1.80^{c}$ & $1.87^{\mathrm{d}}$ \\
\hline S.D. & 0.04 & 0.12 & 0.05 & 0.19 & 0.17 & 0.21 \\
\hline
\end{tabular}

S.D. = standard deviation

Values with different letters, taken at the same time, are significantly different.

cause significant changes in the hardness readings and weight gain data.

\section{Study with acetone and methylene chloride}

Previously, we (Parker and Ranney 1995) observed that a $40 \%$ solution of acetone softened PVC in seven days while a $20 \%$ solution did not.
In a different study, we (Parker and Ranney 1994) observed that PVC was not softened after seven days' contact with a solution containing methylene chloride with a relative solubility of 0.4 . However, in this study, a solution containing methylene chloride with a relative solubility of $0.4(0.76 \%)$ and $0.5 \%$ acetone softened PVC after only four 
Table 11a. Hardness (Barcol) readings of PVC exposed to aqueous solutions of methylene chloride (MC) and acetone.

\begin{tabular}{|c|c|c|c|c|c|c|}
\hline \multirow{2}{*}{\multicolumn{2}{|c|}{$\begin{array}{cc}\text { MC, } & \text { Acetone } \\
\text { Rel.sol. } & (\%) \\
\end{array}$}} & \multicolumn{5}{|c|}{ Contact time, days } \\
\hline & & 2 & 4 & 7 & 14 & 21 \\
\hline \multicolumn{2}{|c|}{ control } & 75 & 75 & 74 & 73 & 74 \\
\hline \multicolumn{2}{|c|}{ control } & 76 & 74 & 76 & 73 & 75 \\
\hline \multicolumn{2}{|c|}{ control } & 76 & 76 & 73 & 74 & 76 \\
\hline \multicolumn{2}{|c|}{ control } & 74 & 74 & 75 & 76 & 75 \\
\hline \multicolumn{2}{|c|}{ control } & 75 & 75 & 76 & 75 & 75 \\
\hline \multicolumn{2}{|c|}{$\bar{X}$} & 75.2 & 74.8 & 74.8 & 74.2 & 75 \\
\hline 0.4 & 0.0 & 73 & 72 & 74 & 73 & 74 \\
\hline 0.4 & 0.0 & 74 & 74 & 74 & 76 & 72 \\
\hline 0.4 & 0.0 & 76 & 73 & 76 & 73 & 75 \\
\hline 0.4 & 0.0 & 75 & 75 & 73 & 74 & 72 \\
\hline 0.4 & 0.0 & 74 & 76 & 73 & 72 & 73 \\
\hline \multicolumn{2}{|c|}{$\bar{X}$} & 74.4 & 74 & 74 & 73.6 & 73.2 \\
\hline 0.4 & 0.5 & 75 & 74 & 71 & 70 & 72 \\
\hline 0.4 & 0.5 & 76 & 70 & 68 & 71 & 72 \\
\hline 0.4 & 0.5 & 74 & 67 & 67 & 67 & 70 \\
\hline 0.4 & 0.5 & 75 & 69 & 70 & 75 & 71 \\
\hline 0.4 & 0.5 & 75 & 68 & 68 & 70 & 70 \\
\hline \multicolumn{2}{|c|}{$\bar{X}$} & 75 & $69.6^{*}$ & $68.8^{*}$ & 70.6 & $71.0^{*}$ \\
\hline 0.4 & 1.0 & 74 & 68 & 66 & 68 & 74 \\
\hline 0.4 & 1.0 & 74 & 69 & 72 & 72 & 71 \\
\hline 0.4 & 1.0 & 75 & 71 & 71 & 67 & 71 \\
\hline 0.4 , & 1.0 & 76 & 67 & 69 & 74 & 73 \\
\hline 0.4 & 1.0 & 75 & 72 & 70 & 73 & 69 \\
\hline \multicolumn{2}{|c|}{$\bar{X}$} & 74.8 & $69.4^{*}$ & $69.6^{*}$ & 70.8 & $71.6^{*}$ \\
\hline 0.4 & 5.0 & 74 & 71 & 70 & 69 & 72 \\
\hline 0.4 & 5.0 & 75 & 68 & 70 & 68 & 69 \\
\hline 0.4 & 5.0 & 74 & 73 & 67 & 71 & 73 \\
\hline 0.4 & 5.0 & 74 & 68 & 69 & 73 & 72 \\
\hline 0.4 & 5.0 & 75 & 70 & 70 & 71 & 72 \\
\hline \multicolumn{2}{|c|}{$\bar{X}$} & 74.4 & $70.0^{*}$ & $69.2^{*}$ & $70.4^{*}$ & $71: 6^{*}$ \\
\hline 0.4 & 10.0 & 75 & $72^{\circ}$ & 71 & 63 & 69 \\
\hline 0.4 & 10.0 & 74 & 68 & 69 & 65 & 72 \\
\hline 0.4 & 10.0 & 74 & 70 & 70 & 69 & 68 \\
\hline 0.4 & 10.0 & 73 & 66 & 68 & 68 & 67 \\
\hline 0.4 & 10.0 & 73 & 67 & 70 & 69 & 68 \\
\hline \multicolumn{2}{|c|}{$\bar{X}$} & 73.8 & $68.6^{*}$ & $69.6^{*}$ & $66.8^{*}$ & $68.8^{*}$ \\
\hline 0.4 , & 20.0 & 67 & 63 & 60 & 54 & 53 \\
\hline 0.4 & 20.0 & 71 & 62 & 54 & 51 & 54 \\
\hline 0.4 & 20.0 & 68 & 65 & 53 & 52 & 48 \\
\hline 0.4 , & 20.0 & 72 & 58 & 59 & 58 & 46 \\
\hline 0.4 & 20.0 & 69 & 60 & 67 & 62 & 45 \\
\hline \multicolumn{2}{|c|}{$\bar{X}$} & $69.4^{*}$ & $61.6^{*}$ & $58.6^{*}$ & $55.4^{*}$ & $49.2^{*}$ \\
\hline
\end{tabular}

*Significantly different from controls.
Table 11b. Percent weight gain of PVC exposed to aqueous solutions of methylene chloride $(\mathrm{MC})$ and acetone.

\begin{tabular}{|c|c|c|c|c|c|c|}
\hline \multirow{2}{*}{$\begin{array}{r}M C, \\
\text { activity }\end{array}$} & \multirow{2}{*}{$\begin{array}{c}\text { Acetone } \\
(\%)\end{array}$} & \multicolumn{5}{|c|}{ Contact time, days } \\
\hline & & 2 & 4 & 7 & 14 & 21 \\
\hline \multicolumn{2}{|c|}{ control } & 0.00 & 0.16 & 0.18 & 0.24 & 0.16 \\
\hline \multicolumn{2}{|c|}{ control } & 0.00 & 0.17 & 0.08 & 0.33 & 0.17 \\
\hline \multicolumn{2}{|c|}{ control } & 0.08 & 0.16 & 0.17 & 0.24 & 0.23 \\
\hline \multicolumn{2}{|c|}{ control } & 0.08 & 0.25 & 0.16 & 0.25 & 0.16 \\
\hline \multicolumn{2}{|c|}{ control } & 0.00 & 0.25 & 0.24 & 0.32 & 0.28 \\
\hline \multicolumn{2}{|c|}{$\bar{X}$} & $0.03^{a}$ & $0.20^{\mathrm{a}}$ & $0.17^{\mathrm{a}}$ & $0.28^{a}$ & $0.20^{\mathrm{a}}$ \\
\hline \multicolumn{2}{|c|}{ S.D. } & 0.04 & 0.05 & 0.06 & 0.04 & 0.05 \\
\hline 0.4 & 0.0 & 0.24 & 0.32 & 0.56 & 0.58 & 0.71 \\
\hline 0.4, & 0.0 & 0.17 & 0.46 & 0.55 & 0.56 & 0.77 \\
\hline 0.4, & 0.0 & 0.26 & 0.40 & 0.56 & 0.61 & 0.87 \\
\hline 0.4, & 0.0 & 0.23 & 0.55 & 0.33 & 0.54 & 0.76 \\
\hline 0.4 & 0.0 & 0.16 & 0.49 & 0.56 & 0.48 & 0.92 \\
\hline \multicolumn{2}{|c|}{$\bar{X}$} & $0.21^{b}$ & $0.44^{a, b}$ & $0.51^{\mathrm{a}, \mathrm{b}}$ & $0.55^{\mathrm{a}}$ & $0.81^{\mathrm{b}}$ \\
\hline \multicolumn{2}{|c|}{ S.D. } & 0.04 & 0.09 & 0.10 & 0.05 & 0.09 \\
\hline 0.4, & 0.5 & 0.16 & 0.57 & 0.62 & 0.84 & 0.70 \\
\hline 0.4 & 0.5 & 0.42 & 0.48 & 0.76 & 1.03 & 0.65 \\
\hline 0.4 & 0.5 & 0.16 & 0.48 & 0.67 & 0.80 & 0.73 \\
\hline 0.4 & 0.5 & 0.16 & 0.58 & 0.65 & 0.89 & 0.82 \\
\hline 0.4 , & 0.5 & 0.26 & 0.33 & 0.63 & 0.95 & 1.01 \\
\hline \multicolumn{2}{|c|}{$\bar{X}$} & $0.23^{b}$ & $0.49^{\mathrm{b}}$ & $0.67^{b}$ & $0.90^{\mathrm{b}}$ & $0.78^{b}$ \\
\hline \multicolumn{2}{|c|}{ S.D. } & 0.11 & 0.10 & 0.05 & 0.09 & 0.14 \\
\hline 0.4 & 1.0 & 0.25 & 0.67 & 0.87 & 1.20 & 0.97 \\
\hline 0.4 & 1.0 & 0.29 & 0.83 & 0.73 & 1.12 & 1.01 \\
\hline 0.4 & 1.0 & 0.16 & 0.70 & 0.51 & 1.12 & 1.00 \\
\hline 0.4 & 1.0 & 0.47 & 0.49 & 0.68 & 1.07 & 1.17 \\
\hline 0.4 & 1.0 & 0.32 & 0.64 & 0.58 & 0.92 & 1.20 \\
\hline \multicolumn{2}{|c|}{$\bar{X}$} & $0.30^{b, c}$ & $0.67^{b}$ & $0.67^{b}$ & $1.09^{\mathrm{b}}$ & $1.07^{b, c}$ \\
\hline \multicolumn{2}{|c|}{ S.D. } & 0.11 & 0.12 & 0.14 & 0.11 & 0.11 \\
\hline 0.4 & 5.0 & 0.42 & 0.75 & 0.76 & 0.91 & 1.07 \\
\hline 0.4 & 5.0 & 0.53 & 0.70 & 0.80 & 0.93 & 1.27 \\
\hline 0.4 & 5.0 & 0.44 & 0.59 & 0.80 & 1.09 & 1.13 \\
\hline 0.4 & 5.0 & 0.33 & 0.64 & 0.73 & 1.22 & 1.20 \\
\hline 0.4 & 5.0 & 0.44 & 0.73 & 0.88 & 1.20 & 1.08 \\
\hline \multicolumn{2}{|c|}{$\bar{X}$} & $0.43^{\mathrm{c}}$ & $0.68^{\mathrm{b}}$ & $0.79^{b}$ & $1.07^{\mathrm{b}}$ & $1.15^{c}$ \\
\hline \multicolumn{2}{|c|}{ S.D. } & 0.07 & 0.07 & 0.06 & 0.15 & 0.08 \\
\hline 0.4 & 10.0 & 0.41 & 1.15 & 1.81 & 2.07 & 2.04 \\
\hline 0.4 & 10.0 & 0.50 & 1.51 & 1.85 & 1.65 & 1.85 \\
\hline 0.4 & 10.0 & 0.50 & 1.12 & 1.58 & 1.79 & 1.87 \\
\hline 0.4 & 10.0 & 0.83 & 0.80 & 1.51 & 1.78 & 1.97 \\
\hline 0.4 & 10.0 & 0.82 & 1.12 & 1.34 & 1.65 & 2.30 \\
\hline \multicolumn{2}{|c|}{$\bar{X}$} & $0.61^{d}$ & $1.14^{\mathrm{c}}$ & $1.62^{\mathrm{c}}$ & $1.79^{\mathrm{c}}$ & $2.01^{\mathrm{d}}$ \\
\hline \multicolumn{2}{|c|}{ S.D. } & 0.20 & 0.25 & 0.21 & 0.17 & 0.18 \\
\hline 0.4 & 20.0 & 2.33 & 4.53 & 6.46 & 6.64 & 6.34 \\
\hline 0.4 & 20.0 & 2.05 & 5.05 & 5.51 & 5.66 & 6.57 \\
\hline 0.4 & 20.0 & 2.00 & 4.70 & 5.58 & 5.91 & 7.35 \\
\hline 0.4 & 20.0 & 2.03 & 4.38 & 4.96 & 6.18 & 7.71 \\
\hline 0.4 & 20.0 & 2.49 & 4.00 & 4.70 & 4.94 & 7.37 \\
\hline & $\bar{r}$ & $2.18^{\mathrm{e}}$ & $4.53^{d}$ & $5.44^{\mathrm{d}}$ & $5.87^{d}$ & $7.07^{\mathrm{e}}$ \\
\hline & D. & 0.22 & 0.39 & 0.68 & 0.63 & 0.58 \\
\hline
\end{tabular}

S.D. = standard deviation

Values with different letters, taken at the same time, are significantly different. 
days' contact (Table 11). Clearly there is a combined effect with these two organic solutes!

\section{CONCLUSIONS}

These data show that when the relative solubility of a single organic solute is less than 0.1 , there will not be any measurable effect on PVC, either weight gain or hardness readings. For solutions that contain several organic solvents, we have found the sum of the relative solubilities of the organic solutes in the test solution to be a useful, if not rudimentary, indicator of the ability of an aqueous solution to degrade PVC. If the sum of the relative solubilites of the organic solutes in solution is less than 0.1 , there does not appear to be any measurable effect on rigid PVC. This relative solubility corresponds to an activity level (0.1) where diffusion is slowest and Fickian. At slightly higher relative solubilities $(0.2,0.4)$, there are slight changes in the hardness readings, although in the time frame of our studies (18 months and less) PVC does not become pliable or rubbery.

We do not have any parameters that can be used to predict the ability of aqueous solutions that also contain PVC solvents and swelling agents that are completely miscible in water to soften PVC. The relative solubility cannot be used to predict the ability of the solution to soften PVC because this involves dividing the concentration of the analyte by an infinitely large number. It is interesting that a $1 \%$ solution of acetone had no effect on the hardness readings after 18 months' exposure, while a solution containing methylene chloride with a relative solubility of $0.4(0.76 \%)$ and $0.5 \%$ acetone softened PVC after only a few days' contact. Clearly, further study is needed to delineate the influence miscible PVC solvents and swelling agents have on the softening ability of aqueous organic solutions.

Previously Leggett and Parker (1994) used a model based on multiparameter linear solvation energy relationships to describe equilibrium partitioning between PVC and water for several organic compounds. Partitioning of these solutes was related to the molecule's acidity, polarity/ polarizability, basicity, and molecular volume. A similar approach might prove useful here for predicting in a more meaningful way the ability of aqueous organic solutions to soften PVC.

\section{LITERATURE CITED}

ASTM (1988) ASTM standard test method D 258387 for indentation hardness of rigid plastics by means of a Barcol Impressor. American Society for Testing and Materials, Philadelphia, Pennsylvania, p. 337-339.

Berens, A.R. (1985) Prediction of organic chemical permeation through PVC pipe. Journal of the American Water Works Association, p. 57-65.

Dean, J.I. (Ed.) (1985) Lange's Handbook of Chemistry, Thirteenth Edition. New York: McGraw-Hill Publishers.

Holsen, T.M. (1988) The effect of soils on the permeation of plastic pipes by organic chemicals. Ph.D. Thesis, University of California-Berkeley. University Microfilms International Dissertation Information Service order number 8902122.

Jenkins, D., R.E. Selleck, L. Bontoux, and D. Soong (1986) Permeation of plastic pipes: Literature review and research needs. Sanitary Engineering and Environmental Health Research Laboratory, College of Engineering, School of Public Health, University of California-Berkeley, SEEHRL Report 86-12.

Leggett, D.C. and L.V. Parker (1994) Modeling the equilibrium partitioning of organic contaminants between PTFE, PVC, and groundwater. Environmental Science and Technology, 28(7): 1229-1233.

Montgommery, J.H. (1991) Groundwater Chemicals Desk Reference. Volume 2. Chelsea, Michigan: Lewis Publishers, Inc.

Montgommery, J.H. and L.M. Welkom (1990) Groundwater Chemicals Desk Reference. Chelsea, Michigan: Lewis Publishers, Inc.

Parker, L.V. and T.A. Ranney (1994) Softening of rigid PVC by aqueous solutions of organic solvents. USA Cold Regions Research and Engineering Laboratory, Special Report 94-27.

Parker, L.V. and T.A. Ranney (1995) Additional studies on the softening of rigid PVC by aqueous solutions of organic solvents. USA Cold Regions Research and Engineering Laboratory, Special Report 95-8.

Parker, L.V., T.A. Ranney, and S. Taylor (1992) Softening of rigid polyvinyl chloride by high concentrations of aqueous solutions of methylene chloride. USA Cold Regions Research and Engineering Laboratory, Special Report 92-12.

Ranney, T.A. and L.V. Parker (1995) Susceptibility of ABS, FEP, FRE, FRP, PTFE, and PVC well casings to degradation by chemicals. USA Cold 
Regions Research and Engineering Laboratory, Special Report 95-1.

Taylor, S. and L.V. Parker (1990) Surface changes in well casing pipe exposed to high concentrations of organics in aqueous solution. USA Cold Regions Research and Engineering Laboratory, Special Report 90-7.

Vonk, M.W. (1985) Permeatie van organische verbindingen door leiding-materialen. In Permeatie en drinkwaterleidingen, KIWA, N.V, Nieuwegein, The Netherlands, KIWA Report 85 (in Dutch with English summary).

Vonk, M.W. (1986) Permeation of organic soil contaminants through polyethylene, polyvinylchloride, asbestos-cement and concrete water pipes. In Proceedings of the American Water Works Association Water Quality Technical Conference, 1985, vol. 13, p. 701-714. 
APPENDIX A: PERCENT WEIGHT GAIN IN PVC EXPOSED TO VARIOUS NEAT ORGANIC CHEMICALS (HEEREMANS, RANNEY AND PARKER; UNPUBLISHED STUDIES)*

\begin{tabular}{|c|c|c|c|c|}
\hline \multirow[b]{2}{*}{ Solvent } & \multicolumn{4}{|c|}{ Percent $\Delta w t$. } \\
\hline & 4 hours & 1 day & 7 days & 55 days \\
\hline acetic acid & 0.0 & 0.2 & - & - \\
\hline acetone & 46.5 & - & - & 150.8 \\
\hline acetonitrile & 1.8 & 5.0 & 11.2 & 13.9 \\
\hline benzene & 2.2 & 5.8 & 23.3 & 47.5 \\
\hline benzonitrile & 26.8 . & - & - & 365.0 \\
\hline benzyl alcohol & 0.0 & 0.0 & 0.0 & 0.1 \\
\hline bromochloromethane & 309.3 & 648.4 & - & - \\
\hline bromodichloromethane & 60.8 & 216.2 & - & - \\
\hline bromoform & 20.8 & 71.1 & - & - \\
\hline butanol & 0.0 & 0.0 & 0.0 & 0.0 \\
\hline butylamine & 14.5 & 59.3 & - & - \\
\hline carbon disulfide & 12.0 & 28.0 & 36.5 & 33.9 \\
\hline carbon tetrachloride & 0.0 & 0.0 & 0.0 & 0.1 \\
\hline chlorobenzene & 11.7 & 52.1 & - & 149.7 \\
\hline chlorodibromomethane & 57.2 & 165.3 & - & - \\
\hline 2-chloroethyl vinyl ether & 7.5 & 25.6 & - & - \\
\hline chloroform & 36.2 & 124.2 & - & 205.1 \\
\hline cyclohexane & 0.0 & 0.1 & 0.0 & 0.0 \\
\hline cyclohexanone & D & & & \\
\hline 1,2-dibromoethane & 27.8 & 105.4 & - & - \\
\hline 1,2-dichlorobenzene & 3.6 & 17.7 & 61.1 & 197.4 \\
\hline 1,3-dichlorobenzene & 3.6 & 13.9 & 47.5 & 100.8 \\
\hline 1,1-dichloroethane & 13.4 & 44.1 & 115.1 & 115.2 \\
\hline 1,2-dichloroethane & 52.6 & 215.5 & - & - \\
\hline cis-1,2-dichloroethylene & 87.3 & 253.0 & - & - \\
\hline trans-1,2-dichloroethylene & 18.7 & 50.7 & - & - \\
\hline 1,2-dichloropropane & 10.5 & 30.8 & - & - \\
\hline 3,4-dimethyl acetophenone & - & 238.9 & - & - \\
\hline dimethyl formamide & 32.5 & $\mathrm{D}$ & & \\
\hline dimethyl sulfoxide & 4.7 & 17.0 & 55.4 & 68.9 \\
\hline dioxane & 4.2 & 14.3 & 51.0 & 104.7 \\
\hline ethanol amine & 0.0 & 0.4 & - & - \\
\hline ethyl acetate & 23.6 & 85.4 & - & 144.4 \\
\hline ethyl benzene & 0.8 & 2.1 & - & - \\
\hline heptane & 0.0 & 0.0 & 0.0 & 0.0 \\
\hline hexane & 0.0 & 0.0 & 0.0 & 0.0 \\
\hline iso-butanol & 0.0 & -0.1 & -0.1 & 0.1 \\
\hline iso-propanol & 0.0 & 0.0 & 0.0 & -0.1 \\
\hline methanol & 0.0 & 0.0 & 0.1 & 0.3 \\
\hline methoxy ethanol & 0.1 & 0.9 & - & - \\
\hline methyl ethyl ketone & - & - & - & 238.8 \\
\hline
\end{tabular}

* Small pieces of PVC well casing $(1 \mathrm{~cm} \times 1 \mathrm{~cm})$ were placed in 22-mL borosilicate glass vials, $5 \mathrm{~mL}$ of solvent was added, and the vials were capped with Teflon-lined plastic caps. Prior to weighing $( \pm 0.0001)$, the samples were blotted with paper towels.

- No data

D PVC dissolved 


\begin{tabular}{lcccc} 
& \multicolumn{5}{c}{ Percent $\Delta$ wt. } \\
\cline { 2 - 5 } \multicolumn{1}{c}{ Solvent } & 4 hours & 1 day & 7 days & 55 days \\
\hline methyl isobutyl ketone & 18.5 & 92.3 & - & - \\
methylene chloride & - & - & - & 388.0 \\
nitrobenzene & 29.6 & - & - & 488.3 \\
o-nitrotoluene & 11.9 & 46.1 & - & 474.5 \\
$m$-nitrotoluene & 14.5 & 51.1 & - & 479.6 \\
propanol & 0.0 & 0.0 & 0.0 & 0.0 \\
pyridine & 122.8 & $\mathrm{D}$ & & \\
1,1,2,2-tetrachloroethane & 6.1 & 32.3 & - & - \\
tetrachloroethylene & 0.1 & 0.1 & 0.3 & 0.3 \\
tetrahydrofuran & 22.9 & $\mathrm{D}$ & & \\
toluene & 2.7 & 8.0 & 32.0 & 49.2 \\
1,1,1-trichloroethane & 0.2 & 0.5 & 1.6 & 4.0 \\
1,1,2-trichloroethane & 22.8 & 83.0 & 328.8 & 368.5 \\
trichloroethylene & 7.6 & 27.8 & 69.7 & 67.8 \\
o-xylene & 0.7 & 2.4 & - & - \\
$m$-xylene & 0.6 & 2.3 & - & - \\
p-xylene & 1.2 & 2.7 & - & - \\
\hline
\end{tabular}


Public reporting burden for this collection of information is estimated to average 1 hour per response, including the time for reviewing instructions, searching existing data sources, gathering and maintaining the data needed, and completing and reviewing the collection of information. Send comments regarding this burden estimate or any other aspect of this collection of information, including suggestion for reducing this burden, to Washington Headquarters Services, Directorate for Information Operations and Reports, 1215 Jefferson Davis Highway, Suite 1204, Arlington, VA 22202-4302, and to the Office of Management and Budget, Paperwork Reduction Project (0704-0188), Washington, DC 20503.

\begin{tabular}{|l|l|l}
\hline 1. AGENCY USE ONLY (Leave blank) & $\begin{array}{c}\text { 2. REPORT DATE } \\
\text { October } 1996\end{array}$ & 3. REPORT TYPE AND DATES COVERED
\end{tabular}

\begin{tabular}{|l|l|}
\hline 4. TITLE AND SUBTITLE & 5. FUNDING NUMBERS
\end{tabular}

Further Studies on the Softening of Rigid PVC by Aqueous Solutions of Organic Solvents

6. AUTHORS

Louise V. Parker and Thomas A. Ranney

7. PERFORMING ORGANIZATION NAME(S) AND ADDRESS(ES)

8. PERFORMING ORGANIZATION REPORT NUMBER

U.S. Army Cold Regions Research and Engineering Laboratory

72 Lyme Road

Special Report 96-26

Hanover, New Hampshire 03755-1290

9. SPONSORING/MONITORING AGENCY NAME(S) AND ADDRESS(ES)

U.S. Army Environmental Center

Aberdeen Proving Ground, Maryland 21010-5401

10. SPONSORING/MONITORING AGENCY REPORT NUMBER

SFIM-AEC-ET-CR-96156

11. SUPPLEMENTARY NOTES

For conversion of SI units to non-SI units of measurement consult ASTM Standard E380-93, Standard Practice for Use of the International System of Units, published by the American Society for Testing and Materials, 1916 Race St., Philadelphia, Pa. 19103.

12a. DISTRIBUTION/AVAILABILITY STATEMENT 12b. DISTRIBUTION CODE

Approved for public release; distribution is unlimited.

Available from NTIS, Springfield, Virginia 22161

13. ABSTRACT (Maximum 200 words)

In this study, small pieces of PVC well casing were exposed to relatively low activities (or relative solubilities) of TCE and methylene chloride for 12 months. PVC pieces were also exposed to aqueous solutions containing several organic chemicals that were either solvents or swelling agents of PVC. In addition, small pieces of PVC were exposed to aqueous solutions containing organic chemicals that were either PVC solvents or swelling agents and were totally miscible in water. These studies revealed that there is an interactive effect among these chemicals when dissolved in water. However, softening does not appear to occur in any solutions where the sum of the relative solubilities is less than 0.1 .

\section{SUBJECT TERMS}

Aqueous solutions Organic solvents

$$
\text { Polyvinyl chloride Softening }
$$
PVC 8. SECURITY CLASSIFICATION OF THIS PAGE UNCLASSIFIED

Solvents
17. SECURITY CLASSIFICATION OF REPORT

UNCLASSIFIED

19. SECURITY CLASSIFICATION
OF ABSTRACT
UNCLASSIFIED

UNCLASSIFIED

\begin{tabular}{|} 
15. NUMBER OF PAGES \\
31 \\
\hline 16. PRICE CODE \\
20. LIMITATION OF ABSTRACT \\
UL
\end{tabular}

